\title{
Identifying Influencing Factors of Audit Risk Model: A Combined Fuzzy ANP-DEMATEL Approach
}

Morteza Shafiee Sardasht. Islamic Azad University of Mashhad. Iran acc.shafiee@gmail.com

Elham Rashedi. AllamehTabataba'i University. Iran e.rashedi90@gmail.com

\begin{abstract}
In the professional circles, factors affecting audit risk are treated independently; however, a more objective approach in assessing detection risk should be involved the relationships among the audit risk factors. This study introduces a framework based on a fuzzy multi-criteria decision support to identify the influencing factors may affect the audit risk model considering the interdependencies among them. We first takes advantages of a fuzzy screening method to screen forty more practical factors may affect the audit risk model out of 58 potential ones. Then, we applied a combined approach of Analytic Network Process (ANP) and Decision-Making Trial and Evaluation Laboratory (DEMATEL) to weight the factors and prioritize them considering their inner and outer dependencies complemented with a case study of Iran. To be more compatible with ambiguities related to human beings and make more useful decisions in the real world, the fuzzy set theory is used. The combined approach used in this study providing correct, precise weight for each factor can explore a more rigorous framework for decision-making in risk assessment by integrating interdependent relationships within and among audit risk factors.
\end{abstract}

Keywords: Audit risk model, Audit risk factors, Analytic Network Process (ANP), Decision Making Trial and Evaluation Laboratory (DEMATEL), Fuzzy Set Theory, Iran.

\section{INTRODUCTION}

Auditors who use audit risk model must assess the detection risk degree. They should decide the degree of detection risk of the plans and the expected collection 
of audit evidence through acceptable audit risk, and the degrees of inherent risk and control risk (Chang et al., 2008). Therefore, to determine detection risk properly would influence the results of the audit.

However, each component of the audit risk model is influenced by various factors. Most studies which have been conducted so far often focus only on the audit risk formula and rarely pay attention to its factors. The risk-based audit will achieve its targets if influencing factors firstly are identified.

As Dusenbury et al. (2000) highlighted proper use of the audit risk model requires the component risks should be characterized as dependent risks. Anyhow, auditing standards, risk-based audit manuals, and the practical procedures individually consider audit risk components and those factors that may affect them. They treat them as independent, separate parts without taking into account any inner and outer interdependencies. Regarding the audit risk model, while the outer dependency is the one-way relationship between the underneath level that affects the upper one, the inner dependency is the relationship within factors of a certain level which are not independent of one another. The former refers to, for example, the dependency between the cluster of Inherent risk and Financial statement level factors and the latter is the dependency among factors of Financial statement level and Account the remaining sum level within Inherent risk cluster (Table 5).

According to Rozario and Vasarhelyi (2018), "the external audit profession substantially lags in technological innovation."In the audit risk context, also, the traditional and normative trends mostly consider the direct and unidirectional effects of each component of the audit risk and their factors independently. Therefore, the interdependencies of them and their mutual effects are ignored in audit risk assessment. As a result, the traditional approach of assessing audit risk may fail to provide a direct and comparable assessment about the importance of the audit risk components and it can increase the opportunity of an undetected material misstatement (Morton et al., 1991).

Moreover, the audit risk and its factors can be mostly influenced by the environment, conditions, rules, and other features of the audit operation. Influenced by such situations, the factors that may affect the audit risk would vary in different environments, cultures, and countries. If localized factors are not 
considered, this inflexibility will compel the audit to experience failure. Obviously, under such conditions, the auditor's judgment on the audit risk, inherent risk, control risk and their effects on the detection risk is intensively subjective or has not been based on the precise hypotheses.

This study provided a multi-criteria decision support framework for identifying the influencing factors that may affect the audit risk model considering interdependencies among them. In doing so, we build the study on already identified detection risk factors by Chang et al. (2008), and aims to utilize a Multiple Criteria Decision Making (MCDM) method using fuzzy ANP and fuzzy DEMATEL that could help deal with these factors in audit risk decision making. Considering audit risk model as a decision-making problem, the characteristics of proposed combined MCDM approach is able to rank factors of audit risk in a more precise and thorough manner considering the inner and outer dependencies found among various factors with due attention to viewpoints of experts familiar with the domestic audit practice. A precise description of influencing factors can make the audit risk assessment more objective and enable auditors to provide type, nature and, the extent of substantive tests and both concentration and timing can be allocated in positions with more risks. Thereby, the audit assessment can be directed from the mental estimations to precise, exhaustive, and practical confirmations. Thus, the proposed model may also positively affect the PCAOB (2015) concern over the significance of deficiencies in risk assessment subject.

Thus, the research question for this study was: Does the combined fuzzy ANPDEMATEL approach could specify the influencing factors of audit risk model considering inner and outer dependency among them and provide weights relevant to each factor?

The remainder of this work is organized into the following four sections. First, a literature review looks at prior literature that informs this study. The next section includes methodology, including both the research question and experiment design. The third section includes the research findings. Finally, the research ends with conclusions, including limitations and future research. 


\section{LITERATURE REVIEW}

\subsection{Risk-Based Audit}

The economic growth and increasing complications of business during the past decades have resulted in separating ownership from management. Following such development, the auditing methodology has necessarily passed an improving path and manifested through different approaches.

Changes in auditing methodology often have been occurred when the efficiency of the current techniques has been contested in professional units or courts; so the auditors have been impelled to find solutions to eliminate deficiencies and reforming the audit process. This evolutionary process, which in fact is the resultant of adapting auditing methodology on the requirements of societies, can be sorted into four certain approaches: The substantive procedures approach, the balance sheet approach, the systems-based approach and the risk-based approach.

Audit risk would first arise under which conditions that auditors tried to use the statistical sampling methods into the audit. Using those statistical methods to determine sample size, it was found the samples were often far greater than those which were provided by the auditors' judgments. Counting on risk-based approach, some persuasive reasons have developed to respond the question of why auditors can rely on more little sample rather than those which traditional, statistical techniques prescribed. In fact, audit risk management supports auditors to define sample size regarding the risk and planned materiality.

Although, risk is an integral part of auditing (Jankûnaitë et al., 2005), before lawsuits against auditors which the Arthur Andersen LLP was one of the most important of them, auditing process used to be directed with a little (if any) attention to its risks (Imoniana and Gartner, 2008). According to Hayes, et al. (2005), audit risk refers to the risk that an auditor may issue an unqualified report due to the auditor's failure to detect material misstatement. To dominate this, riskbased audit first requires identifying those high-risk areas which necessitate extensive scurvies. Then, it has to distinguish how the audit methods for low-risk areas should be decreased. 
Audit risk model by current characteristics, at first was given authoritative support by the publication of SAS No. 39 (AICPA, 1981) and then SAS No. 47 (AICPA, 1983). Combining the analytical procedures risk and the test of details risk, the SAS 39 introduced them as detection risk. However, the SAS No. 47, unlike SAS No.39, puts a certain emphasis on using audit risk and materiality simultaneously to determine the nature, timing, and extent of audit procedures. According to SAS No. 47, a global audit risk has to decompose into component risks that are used as inputs of the audit risk model.

The increasing care of risk assessment in the US was followed by issuing SAS No. 82 (1997). Then a revision trend has been continued on the following standards such as replacing the SAS No. 47 by SAS No. 107 (2006). Recently the PCAOB has also urged to focus on risk assessments standards. Auditing Standards No. 8 through No. 15 addresses the auditor's assessment of and response to the risk of material misstatements in financial statements. The efforts have continued issuing new reference (AS 1101) after reorganizing PCAOB auditing standards, which is effective as of December 31, 2016.

The overall amendments somehow are then followed by International Standards on Auditing and the Iranian auditing standards, respectively.

According to AICPA (1983), the audit risk (AR) consists of three components including inherent risk (IR), control risk $(C R)$, and detection risk $(D R)$; thus the classical audit risk model is expressed as $A R=I R \times C R \times D R$. An auditor, at first, needs to determine the acceptable audit risk. Then the inherent risk is assessed at the management level and the business unit as a whole, and it is then followed by the assessment of the control risk. Finally, auditing techniques are extended so that the detection risk, after combining with inherent and control risks, can lessen the audit risk to the acceptable level that has been expected at first (Spector, 2007). Therefore, by adjusting the classical model, the audit risk model can be shown as: $\quad D R=\frac{A R}{I R \times C R}$.

Then, to keep detection risk at the assessed degree, and, in return, predetermined audit risk level, auditors should choose a certain amount of evidence and samples of accounts. It means there is a reverse relation between audit evidence and audit 
risk. Therefore, when the factors influencing detection risk are more objective and correct, the more proper evidence is collected and audit costs and the risk of audit failure can be lessened (Chang et al., 2008). Figure 1 describes the relation among of audit risk components, their influencing factors, the significant level, and audit evidence.

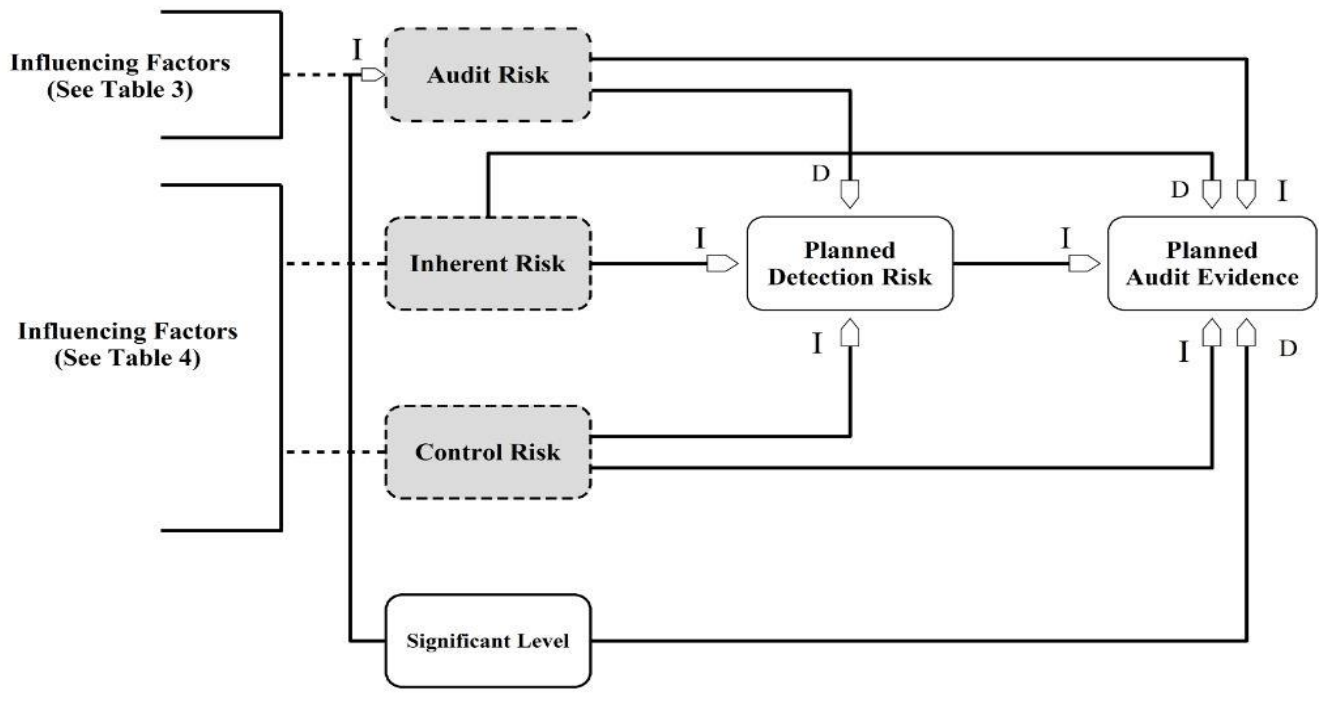

D = Direct Relationship ; I = Inverse Relationship

Figure 1. Relation among of audit risk components, influencing factors significant level and audit evidence (Adapted from Chang et al., 2008).

However, in performing detection risk assessment, auditors will use their professional judgment based on their previous experiences and knowledge either generally or specifically (Ritchie and Khorwatt, 2007). As Turner et al. (2002) stated studies cast doubt about auditors' professional judgmental ability to recognize audit evidence and proper responses. Thus, the auditors should be meticulous and careful to evaluate the detection risk (Chang et al., 2008).

Regarding audit risk model, there are factors each one may finally affect detection risk and then audit evidence and size of samples. To identify influencing and objective factors could reduce the risk of audit failure and result in more efficiency and effectiveness of audit. This research considering inner and outer 
relations among the factors may affect audit risk, prepare a framework to assess the detection risk in a more objective way.

In the opinion of Beatie et al. (2002) influencing factors on audit risk could classify into "Auditor Base" and "Auditee Base". Also, "Financial Statement Level" and "Account Remaining Sum Level" are two major groups affecting inherent risk. In addition, as reported by the Committee of Sponsoring Organization of the Tradeway Commission (1996) the internal control is formed by five coherent parts: "Control Environment", "Risk Assessment", "Control Activities", "Information \& Communication", and "Supervision" which have inseparable bond with management process.

This method of acting is prevalent, and it also has adopted by the Iranian auditing standards, but the revised Iranian auditing standard of No. 315 (Iran Audit Organization, 2013) has replaced the "Information \& Communication" with "Information Systems". In this paper, we put the "Accounting Process and Financial Reporting" as a sole factor of this part into "Control Activity" main factor. All the components of this study are included as main audit risk factors showing in Table 1.

\begin{tabular}{|c|c|c|}
\hline & Component & Main factor \\
\hline \multirow{8}{*}{ 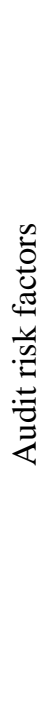 } & \multirow{4}{*}{ Control risk } & Supervision \\
\hline & & Control activity \\
\hline & & Risk assessment \\
\hline & & Control environment \\
\hline & \multirow{2}{*}{ Inherent risk } & Account the remaining sum level \\
\hline & & Financial statement level \\
\hline & \multirow{2}{*}{ Audit risk } & Auditee base \\
\hline & & Audit base \\
\hline
\end{tabular}

Table 1. Audit risk components and their main factors 
According to Beasley et al., (2001) the audit quality through having lesser audit risk has a contrary direction with audit failure. Thus, if the auditors subjectively judge the influences of audit risk, inherent risk, and control risk on detection risk, it might lead to an inefficient distribution of resources, ineffective audit results and, increase the risk of audit failure (Mock et al., 1998; Krishnan and Krishnan, 1997; Bedard and Graham, 2002; Khurana and Raman, 2004; Low, 2004, Chang et al., 2008); therefore, audit risk assessment should be more objective, correct, and precise. However, prior events in the auditing profession such as the demise of Arthur Andersen and the many audit failures have called for a reconsideration of the prevailing paradigms in risk assessment (Srivastava, 2005).

Given the limitations, some researchers have discussed alternative approaches to model audit risk. For example, McCray (1984) introduced a Quasi-Bayesian audit risk model for dollar unit sampling. Another highly developed alternative model is the belief-function model, which is less restrictive in its covenants.

It has been extended, for example, in Shafer and Srivastava (1990), Srivastava and Shafer (1992), Dutta, et al. (1993), Srivastava and Dutta (2002), Srivastava and Mock (2002), Harrison et al. (2002), Sun et al. (2006), Srivastava and Shafer (2008), Srivastava (2011), Srivastava et al. (2011) and, Nehmer and Srivastava (2016). Recently, some researchers also believe fuzzy systems are suitable mathematical modeling for uncertain conditions such as those professional, complex judgments in assessing risks of audit (Friedlob and Schleifer, 1999; Lin et al., 2003; Chang et al., 2008; Huang et al., 2009; Comunale et al., 2010; Bulyga et al., 2016).

However, no existing studies provide evidence on the interdependent relationship among the factors affecting audit risk components. This study counting on fundamental aspects of the audit risk model have proposed a new application of ANP-DEMATEL to weight the factors may affect audit risk. Considering inner and outer dependency among factors, the proposed method can finally provide a detailed approach to weighting factors to create a more objective assessment of detection risk. 


\subsection{Codification of auditing standards in Iran}

Historically, auditing in Iran first came to light in the Income Tax Law of 1949.Based on Law of 1949, the official bodies (such as stock exchange, credit institutions and, judicial system) had to welcome auditors 'examination of accounts. This was also repeated in Income Tax Law of 1956. Then the Center of Iranian Official Accountants was established according to the Direct Tax Law of 1966.An amendment to the Iranian Commercial Code of 1969 has obliged public joint stock companies to accompany their audit report to financial statements. Tehran Stock Exchange Law also required companies registered on the Tehran Stock Exchange (TSE) to be audited.

The Islamic Revolution in Iran in 1979 caused many companies and other economic organizations were devolved to the direct governmental supervision. During 1980 to 1983 three large audit firms were established in the public sector to audit those companies. In 1983, an act ratified by the Iranian national parliament merged the three audit firms to establish the Audit Organization. The Audit Organization's articles of association were then approved by Parliament in 1987 when the Organization was established as a legal entity with financial independence. According to articles of association, the Audit Organization is the official setting responsible for standard setting in Iran and to publish specialized sets of accounting and auditing manuals.

Accounting Standards and Audit Standards of Iran, like many countries, has been developed based on International Standards for more global convergence considering domestic circumstances. Therefore, in most cases, standard setting follows the publication of new international standards. Although here are allowed the listed companies on the Tehran Stock Exchange (TSE) to adopt the International Financial Reporting Standards (IFRS), they have to be effective as of 2015.

Generally, Auditing Standards Setting Committee in Iran considering International Standards on Auditing (ISA) publishes a primary draft of the audit standards for public comments. Then, the committee regarding the comments and current circumstances in the country develops the standards draft. After making necessary amendments, the revised standard draft is presented to the Board of 
Executives of the Organization and then to Board of Governors of the Organization for final approval. Currently, there are 40 effective audit standards which are approved by aforementioned bodies.

Recent changes in risk-based auditing standards developed by AICPA bring about improvements in International Standards on Auditing (ISA) and then to review in audit risk standards in Iran. Figure 2 shows the quality of risk-based audit in Iran.

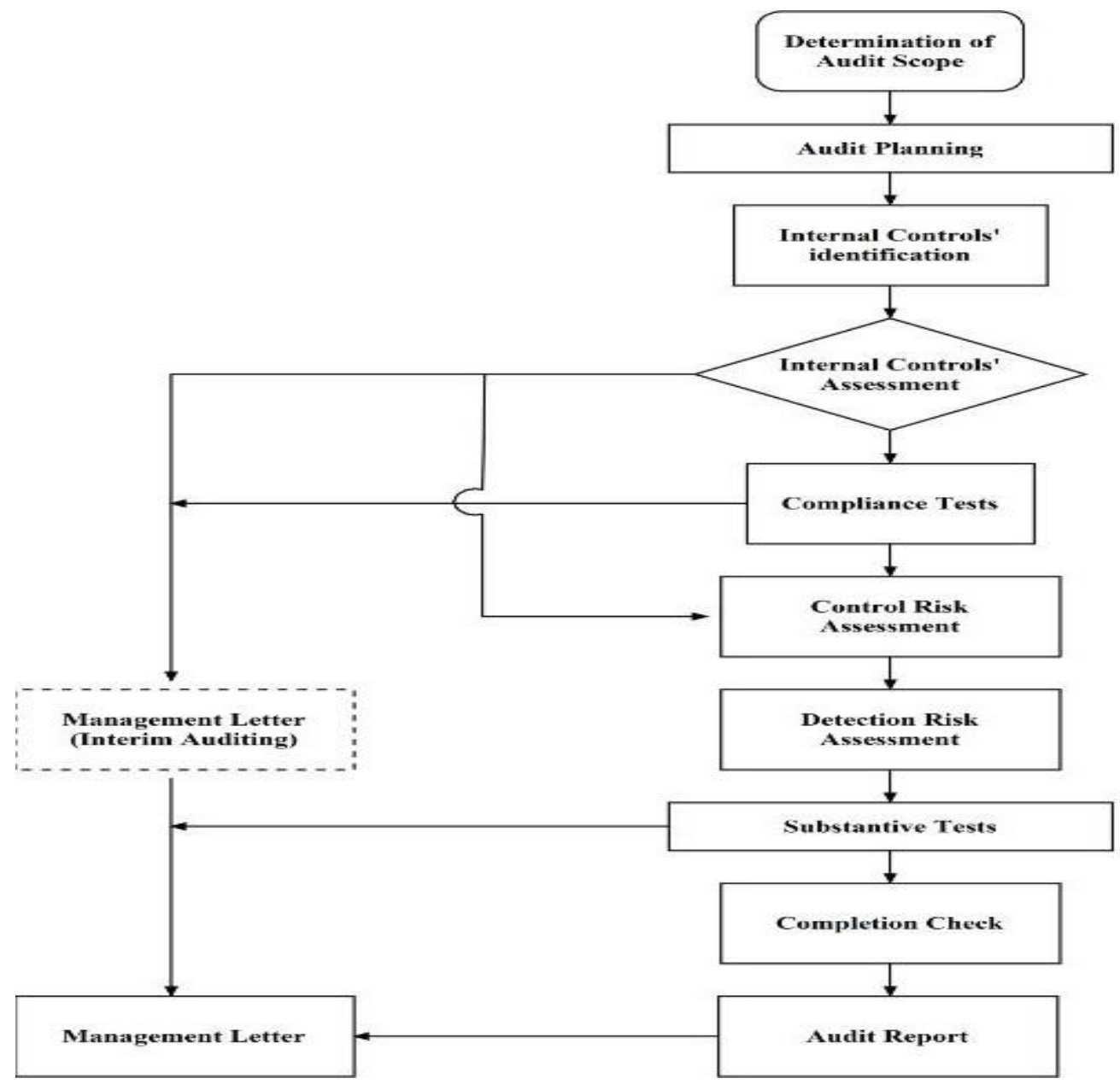

Figure 2. The Quality of Risk-based Audit in Iran (Iranian Audit manual: partially revised to include audit risk management, 2000) 


\subsection{Analytic Network Process (ANP)}

ANP (Saaty, 1996) is one of the Multi-criteria decision making approaches seems to be a proper tool for decision-making problems especially those consisting several conflicting criteria (Factors). The characteristics make ANP popular in the various academic works. For example, Tseng (2011) discussed an ANP based work to evaluate firm environmental knowledge management determining the most influencing criteria for firm improvement.

Considering supplier selection as a multi-objective problem many studies have used ANP to evaluate vendors and select best of them (Gencer and Gürpinar, 2007; Bayazit, 2006).

$\mathrm{Wu}$ and Lee (2007) also employed an ANP method in order to evaluate and select knowledge management strategies to make the framework for the successful implementation of knowledge management. Selecting appropriate contractor can positively affect the project; considering the argument, Cheng and Li (2004) used the ANP to evaluate contractors and select best of them based on certain criteria.

Technically, ANP is a developed form of the Analytic Hierarchy Process (AHP). AHP was developed by Saaty $(1977,1980)$ whose purpose is to choose an appropriate alternative based on multiple criteria. Also, this technique by providing certain weights to each criterion finally can prioritize them.

Although AHP helps analysts to organize the critical aspects of a problem into a hierarchical structure similar to a family tree (Sevkli et al., 2008), the basic assumption of this technique is that each decision level is only dependent on the level immediately above it. Many multi-criteria decision problems-such as audit risk-cannot be considered in terms of a hierarchical structure due to their inner and outer dependency. By replacing hierarchy with the network, ANP does not impose a hierarchical structure on the problem and models the problem using a feedback system approach. In the Feedback System model, levels link one by one in turn as a network system (Wu, 2008). Thus, with a comprehensive framework, the ANP technique can consider all the interactions and relationships between decision levels, forming a network structure (Saaty, 2004). Figure 3 shows the structural difference between hierarchy and network. 


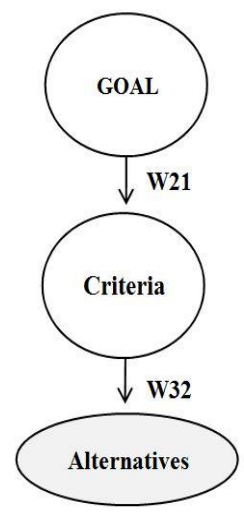

(a)

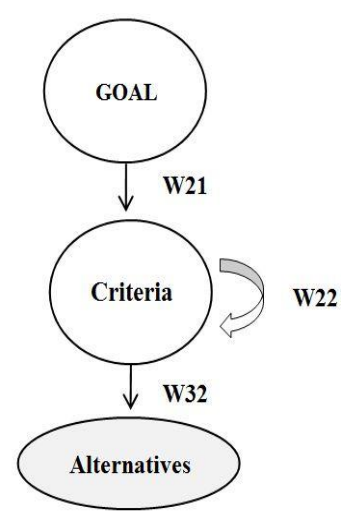

(b)

Figure 3. Difference between a hierarchy and a network: (a) a hierarchy; (b) a network

In the Figure, the $\boldsymbol{W} \mathbf{2 1}$ and $\boldsymbol{W} 32$ are the vectors denoting the effects of goal on criteria and criteria on alternatives in the order given (i.e. outer relation). Also, if criteria involving inner dependencies, the hierarchy turns into a network and the matrix $\boldsymbol{W} 22$ shows those dependencies (inner relation).

The audit risk model involves the evaluation of three different components and their factors by professionals. The factors may have inner and outer relations among them; therefore, considering the use of ANP and selecting influencing of them make possible to increase the success of detection risk assessment in a more objective way and increase the audit quality.

\subsection{Decision Making Trial and Evaluation Laboratory (DEMATEL)}

During applying ANP, the relationship among criteria (factors) should be properly determined. Although, ANP provides the evaluation of the influence and interdependence of the factors, sometimes, this not clear by decision makers (Ortíz et al., 2015). Accordingly, even though ANP has been successfully applied in many fields, the related studies deal imperfectly and incompletely with inner dependences. In an interdependent system, all criteria of the systems are mutually related directly or indirectly. One of the singular solutions for the problem is DEMATEL technique. In such cases, the DEMATEL not only convert the relationships between cause and effect of criteria into a visual structural model, 
but it also can be used as a practical way to handle the inner dependences within a set of criteria (Tseng, 2011).

Based on pair wise comparisons, DEMATEL method converts the relationship between the causes and effects of criteria into an intelligible structural model of the system (Tsai and Chou, 2009). Thus, as a complementary strategy to improve the comprehension of the decision-making problems (Sipahi and Timor, 2010), the combined approach of ANP-DEMATEL can create more accurate results.

The combined ANP-DEMATEL has been also used in the research fields. For example, $\mathrm{Wu}$ (2008) argued to perform knowledge management effectively causes competitive advantages. Therefore, to employ a favorable knowledge management strategy he proposed a combined ANP-DEMATEL approach. Tseng (2009) also used the combined approach to municipal solid waste management (MSW). He questioned, "How the expert group can better evaluate and select a favorable MSW management solution using a series of criteria". Using ANP and DEMATEL he provided an avenue to assist the experts to evaluate different MSW management solutions. Lee et al., (2011) employed the aforementioned method to study the interdependent relationships of the key factors of equity investment. To weight and prioritize the critical success factors in project success, Nilashi et al., (2015) also used the combined ANP-DEMATEL method. Considering five main criteria and 43 sub-criteria the proposed MCDM model produced the weighted factors for the construction project success. Figure 4 illustrates a sample of combined ANP-DEMATEL approach.

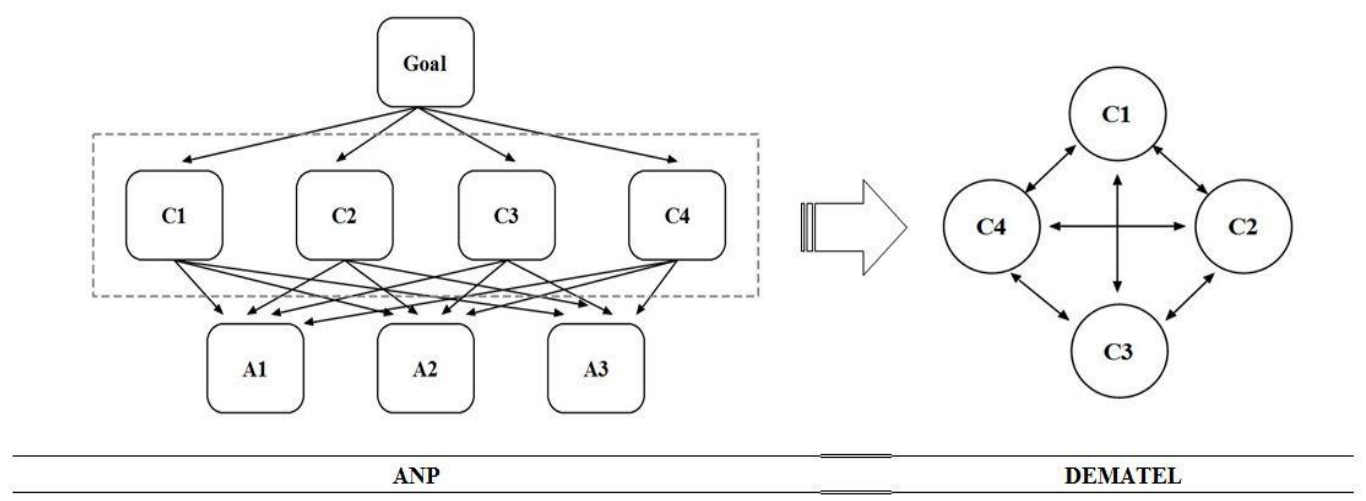

Figure 4. Combined ANP-DEMATEL approach 


\subsection{Fuzzy logic}

According to the fuzzy sets theory, the more complexity of a system, the less the accuracy and the significance of the human's judgment power. The aim of fuzzy sets theory is to solve the uncertainty or fuzzy data in real-world problems (Chang et al., 2008). In MCDM methods, which are largely based on the experts' views, it is usually hypothesized the final decision of an option is issued as a crisp number; while in the real world, it would not be observed. Thus, the subjective nature of human thinking in the decision-making process, usually have faced us with uncertain and fuzzy circumstances in evaluating criteria (Ghorabaee, 2016). To dominate this problem, fuzzy sets theory can be used in MCDM.

In the pairwise comparison, in ANP, is made using a ratio scale. Even though the discrete scale has the advantages of simplicity and ease of use, it does not take into account the uncertainty associated with the mapping of one's perception or judgment to a number (Pourjavad and Shirouyehzad, 2014). In the literature there are many types of research have applied fuzzy ANP in the different fields; for example Dağdeviren et al., (2008); Vinodh et al., (2016); Kumru and Kumru (2015); Altintas et al., (2016).

Moreover, although DEMATEL is a singular technique for evaluating problems, the relationships of systems are generally given by crisp values in establishing a structural model. However, as previously noted, in the real conditions, crisp values are inadequate. Similarly, considering factors evaluation of audit risk model as a decision-making problem, it usually involves information from experts with the different technical background. It means the decisions are made by a group of decision makers which are affected by uncertainty. In these cases, the fuzzy DEMATEL is one of the best tools for dealing with the uncertainty included in those judgments. Thus, in this MCDM based research, we apply fuzzy sets theory to the DEMATEL method for solving uncertain factors problem as well (Büyüközkanand and Çifçi, 2012).

In various areas there arealso various fuzzy DEMATEL studies such as Chang et al., (2011); Lin (2013); Altuntas et al., (2014); Tsai et al., (2015); Mentes et al., (2015); Shen et al., (2017). 
There are also studies have applied the combined approach of fuzzy ANPDEMATEL in decision-making problems. For example, argued that the green strategies of companies have become critical as the public awareness increased against their environmental effects, Büyüközkan, and Çifçi (2012) applied a combined fuzzy ANP-DEMATEL based to propose an evaluation framework for green suppliers. Kabak (2013) use a combined ANP-DEMATEL based multicriteriadecision-making approach to evaluate and choose the best candidates applying for a certain job in the organization. Liou et al., (2014) to supplier improvement and selection also employed the combined fuzzy approach. Applied an ANP-DEMATEL approach in a fuzzy environment by Yeh and Huang (2014), they also examined the key factors considered in determining the location of wind farms. Lean Six Sigma project selection is another application of the fuzzy combined MCDM approach by Vinodh and Swarnakar (2015). The result of the paper signified the optimal Lean Six Sigma project to implement. Vinodh, et al., (2016) proposal of a hybrid MCDM approach for selecting the best concept design of an automobile component is another example of the combined approach.

\section{RESEARCH METHODOLOGY}

\subsection{Experiment Process}

Regarding the factors affecting audit risk, in this study, we proposed a new application of a combined MCDM model to weight and prioritize all factors may affect audit risk. MCDM models, which are resourceful in the complicated decision makings, are able to weight factors or to choose a proper alternative out of the others. In this research, first data (i.e. factors may affect Audit risk) are considered through a work by Chang et al., (2008) (see section 3.3.1). The factors they used are those could affect detection risk and are frequently mentioned in the past literature.

Then, based on first-round questionnaire (section 3.3.2), those less practical factors are eliminated by a fuzzy screening model (section 3.3.2). Next, the residual factors were applied in ANP to prioritize them based on the second-round questionnaire (section 3.3.3). Considering factors which involve in audit risk as a hierarchical tree; first, it is clear the underneath levels affect the upper levels (e.g., the factor of Control environment can affect Control risk and so forth); and 
second, factors are laid in the same level are not independent from each other (e.g., Control environment and Control activity as Control risk factors can be dependent). In such cases, using ANP, as a MCDM method, will result in more accuracy. What makes this method distinguished from other decision-making methods is its special attention to the interdependency between decision-making factors.

Likewise, to specify the internal relations (interdependencies or inner relations) among the audit risk factors, considering second-round questionnaire, the DEMATEL technique was applied through a certain step of ANP (see section 3.3.3.2). Finally, the ultimate weights of the audit risk factors were added and results went back again to ANP method (section 3.3.3.3).

Moreover, since either ANP or DEMATEL are based on experts' views, fuzzy logic was used to deal with fuzzy linguistic statements. The proposed model can provide a framework to focus on those factors that create a great influence on audit risk assessment. Those specified audit risk factors with regard to their weights could improve assessing detection risk and finally reduce audit failure.

In order to confirm the feasibility and usability of the proposed model, the fuzzy, the combined approach was implemented in the Iranian audit profession as a case study. Figure 5 shows the phases to complete experiment process for this study.

\subsection{Case study and data collection process}

Considering Chang et al., (2008) and the Iranian experts' views, the 58 potential factors affecting the audit risk were considered as research's data. For the statistical population, we employ Iranian auditors with specific criteria of passing the CPA exam are operative in the practical audit circle.

The methodology used for data collection is a two-rounded process of the questionnaire as the research instrument. Firstly, regarding the statistical population of 1253 Iranian CPAs are full-time operative in auditing at the time of this research, a sample size of 89 questionnaires was randomly selected. To pinpoint the sample, we used Stratified sampling method and the Cochran's sample size formula. 


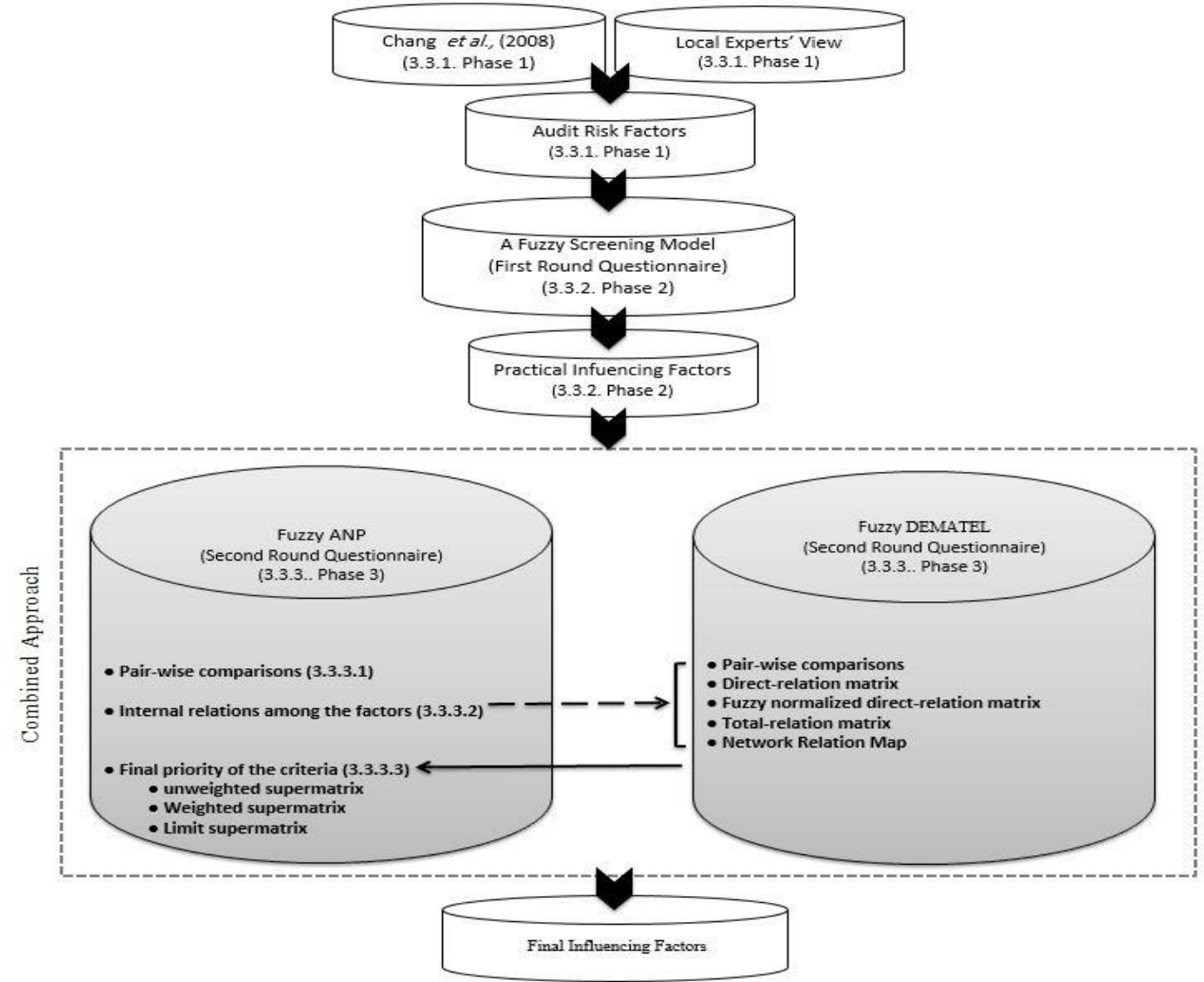

Figure 5. Experiment process

Also, to guarantee an admissible return rate of research instrument and generalization implication, we engage a 20 percent incremental coefficient for all stratifications; thus, the 107 questionnaires were finally determined and handed out by email to the samples (Table 2). Table 3 also describes the demographics of the participants of the first-round of data collection. Those 107 participants in this round were asked their opinion of the importance of the audit risk factors on audit risk assessment in terms of a Likert 5-point scale.

Regarding the return rate of $91 \%$, out of 107 first-round questionnaires, only 97 ones were considered as the basis of measurements. To internal consistency (Reliability), we conducted the Cronbach's Alpha. The calculated score of 0.935 of Alpha has showed to be an acceptable reliability coefficient and thus we faced a 
reliable research instrument in this phase. Also, the validity of the questionnaire was examined using internal-consistency method (Oppenheim, 2000). Regarding the method, a prototype of questionnaires is first handed out to a smaller group of Iranian CPAs based on open-ended questions and then the correlation coefficient of each factor has been compared with total scores of others. By doing so, we could determine factors with smaller correlation coefficient and finally revise them. The final results of this phase were applied to a fuzzy screening methodin order to specify more practical audit risk factors.

\begin{tabular}{|c|c|c|c|c|c|}
\hline \multirow{2}{*}{ Type of Auditors } & \multirow{2}{*}{ Member } & \multirow{2}{*}{$\begin{array}{l}\text { Sample size } \\
\text { (Cochran } \\
\text { formula) }\end{array}$} & \multirow{2}{*}{$\begin{array}{c}\text { Sample size } \\
\text { (20\% incremental } \\
\text { coefficient })\end{array}$} & \multicolumn{2}{|c|}{ Return rate } \\
\hline & & & & $\begin{array}{c}\text { N. of } \\
\text { questioners }\end{array}$ & Frequency \\
\hline $\begin{array}{l}\text { Operative CPAs in Audit } \\
\text { Firms }\end{array}$ & 808 & 57 & 69 & 60 & $62 \%$ \\
\hline $\begin{array}{l}\text { Operative CPAs in Audit } \\
\text { Organization }\end{array}$ & 271 & 19 & 23 & 23 & $26 \%$ \\
\hline $\begin{array}{l}\text { Individual Operative } \\
\text { CPAs }\end{array}$ & 174 & 12 & 15 & 14 & $12 \%$ \\
\hline Total of Operative CPAs & 1253 & 89 & 107 & 97 & $100 \%$ \\
\hline Non-operative CPAs & 492 & & & & \\
\hline $\begin{array}{l}\text { Total of Non-operative } \\
\text { CPAs }\end{array}$ & 492 & & & & \\
\hline Total & 1745 & & & & \\
\hline
\end{tabular}

*Operative: CPAs who participate in audit practice

*Non-operative: CPAs who not participate in audit practice

Table 2. Summary auditors' stratifications and their return rate

Secondly, in the second-round of data collection, we focused on 15 certain Iranian audit experts to conduct fuzzy ANP (A 9-point pairwise evaluation scale questionnaire) and fuzzy DEMATEL (A 5-point pairwise evaluation scale questionnaire). 


\begin{tabular}{|c|c|c|c|c|c|c|c|}
\hline \multicolumn{2}{|c|}{ Education } & \multicolumn{2}{|c|}{ Discipline } & \multicolumn{2}{|c|}{ Professional Records } & \multicolumn{2}{|c|}{ Grade } \\
\hline Degree & Frequency & Major & Frequency & $\begin{array}{c}\text { Experience } \\
\text { (Year) }\end{array}$ & Frequency & Level & Frequency \\
\hline Bachelor & 48 & Accounting & 74 & $\begin{array}{l}\text { Less than } \\
5\end{array}$ & 0 & Manager & 73 \\
\hline Masters & 48 & Finance & 9 & $\begin{array}{l}\text { Between } 5 \\
\text { to } 10\end{array}$ & 13 & Supervisor & 21 \\
\hline $\mathrm{PhD}$ & 1 & Business & 8 & $\begin{array}{l}\text { Between } \\
10 \text { to } 15\end{array}$ & 15 & $\begin{array}{l}\text { Senior } \\
\text { Auditor }\end{array}$ & 1 \\
\hline Total & 97 & Rest & 6 & $\begin{array}{l}\text { More than } \\
15\end{array}$ & 69 & Rest & 2 \\
\hline & & Total & 97 & Total & 97 & Total & 97 \\
\hline
\end{tabular}

Table 3. Demographics of the participants

Since the quality of experts involved in this round was important, the participants were chosen from those academic CPAs having the criteria of over 15 years of professional audit experiences and extensive research interests in the audit literature. To collect opinions and views of the experts, in this round of data collection, they were firstly questioned on their preferences (or importance) of audit risk factors in comparison with each other (ANP questionnaire)and then the mutual impact of the factors are asked (DEMATEL questionnaire) in terms of the pairwise comparisons.

It should be noted that the results of pairwise comparisons should be analyzed via consistency rate $(C R)$. Saaty (1980) considered $C R$ to evaluate the consistency of pairwise comparisons in a matrix among factors. Since for each pairwise comparison matrix, the assessed $C R$ of this phase was smaller than $0.1(\mathrm{CR}<0.1)$, therefore, the questionnaires' reliability of the second round data collection was also accepted (Zeshui and Cuiping, 1999), otherwise the judgment matrix was inconsistent (Unacceptable consistency). 


\subsection{Experiments}

\subsubsection{Phase 1}

As noted earlier, in the first phase, the potential factors affecting the audit risk need to be identified. We consider Chang et al., (2008) to identify 52 factors that may affect audit risk. Chang et al., (2008) used the grounded theory to reorganize and analyze the factors influencing detection risk in the past literature and allocated them into three dimensions (audit risk, inherent risk, and control risk) according to the audit risk model. To be more compatible with the Iranian audit professional circle, we also considered six more factors to the above list and reclassified them taking into account Iranian auditing standards and views of several local audit experts.

Tables 4 and 5 show the final list of affecting factors sorted into "Audit risk group" and "Inherent risk \& Control risk group". This grouping is almost advocated by the nature of Audit risk model. Meanwhile, as reported by ISA 200, Waller (1994); Monroe et al., (1993); Helliar et al., (1996); Messier and Austen (2000); Dusenbury et al., (2000); Hayes et al., (2005); Gramling et al., (2011), it is difficult to separate an organization's internal controls and inherent risk; accordingly, we sorted the potential factors influencing those components into "Inherent risk \& Control risk group" as a whole.

\subsubsection{Phase 2}

In order to increase the contribution of the research to audit cases, we then adopted a fuzzy screening method based on the first-round of data collection questionnaires to the Iranian CPAs in empirical audit circles. The fuzzy screening system introduced by Yager (1993) is a fuzzy screening to select, from a large class of alternatives, a small subset to be further investigated. The individual experts' evaluation is aggregated to get an overall linguistic value for each object. This overall evaluation can be then used by the decision maker as an aid in the selection process (Carlsson and Fullér, 1995).

By doing so, we could remove redundant, trivial factors to conduct the proposed model properly. That is to say, to eliminate less important, empirical factors we not only advocated the pairwise comparisons in fuzzy combined proposed method 
to become more effective but also created a list of more practical, contributing audit risk factors to robust the results of the second round of data collection analysis.

\begin{tabular}{|c|c|c|c|c|c|c|c|c|c|c|c|c|c|}
\hline 1 & 2 & 3 & 4 & 5 & 6 & 7 & 8 & 9 & 10 & 11 & 12 & 13 & 14 \\
\hline \multicolumn{14}{|c|}{ Audit risk factors } \\
\hline \multicolumn{9}{|c|}{ Audit base (C1) } & \multicolumn{5}{|c|}{ Auditee base (C2) } \\
\hline$\stackrel{\Omega}{=}$ & $\frac{\infty}{N}$ & & $\tilde{\omega}$ & & $\frac{n}{1}$ & $\frac{n}{u}$ & & & & $\mathbb{N}$ & $\mathbb{N}$ & & \\
\hline 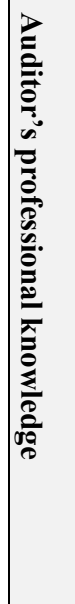 & 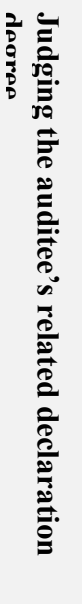 & 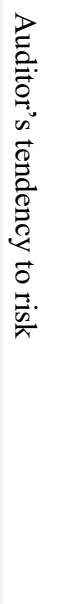 & 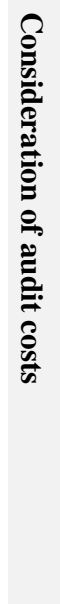 & 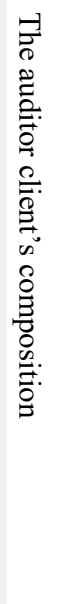 & 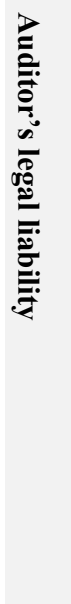 & 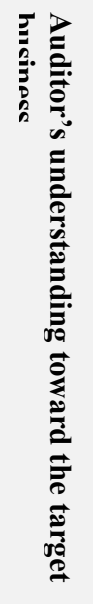 & 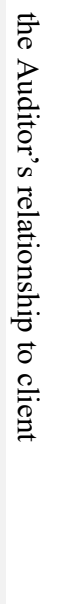 & 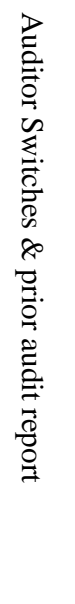 & 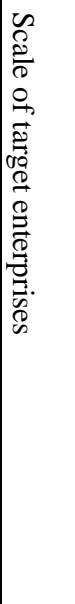 & 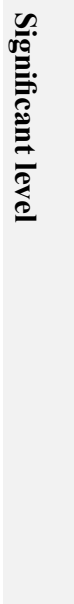 & 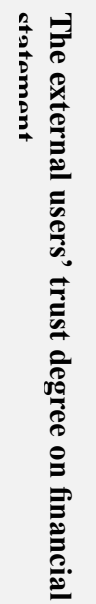 & 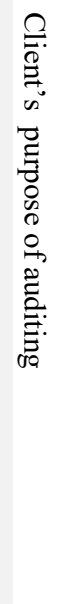 & 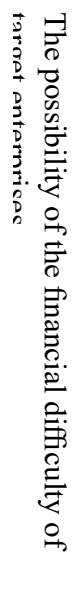 \\
\hline
\end{tabular}

${ }^{*} \mathrm{C}=$ Criteria (Main factor), $\mathrm{S}=$ Sub-criteria (Secondary factor), Bold Items: Factors that are continuing to the next phase

Table 4. Phase 1: Potential audit risk factors affecting the first group of "Audit risk group"

As earlier mentioned, the distribution target for the first-round data collection was 107 certified public accountants in Iranian accounting firms. Relying on the data gathered through the Likert-type scale questionnaire of this round, the results of fuzzy screening technique using Microsoft Excel were provided. To the process, we first fuzzyfy the Likert scales using triangular membership functions. The fuzzification process is a mapping from an input conventional universe of discourse into the fuzzy interval $(0,1)$ that describes the membership of the fuzzy input variable (Khan and Ansari, 2012). The membership function is used to associate a grade to each linguistic term. A membership function, in fact, gives the membership degrees of a variable to a certain set. 


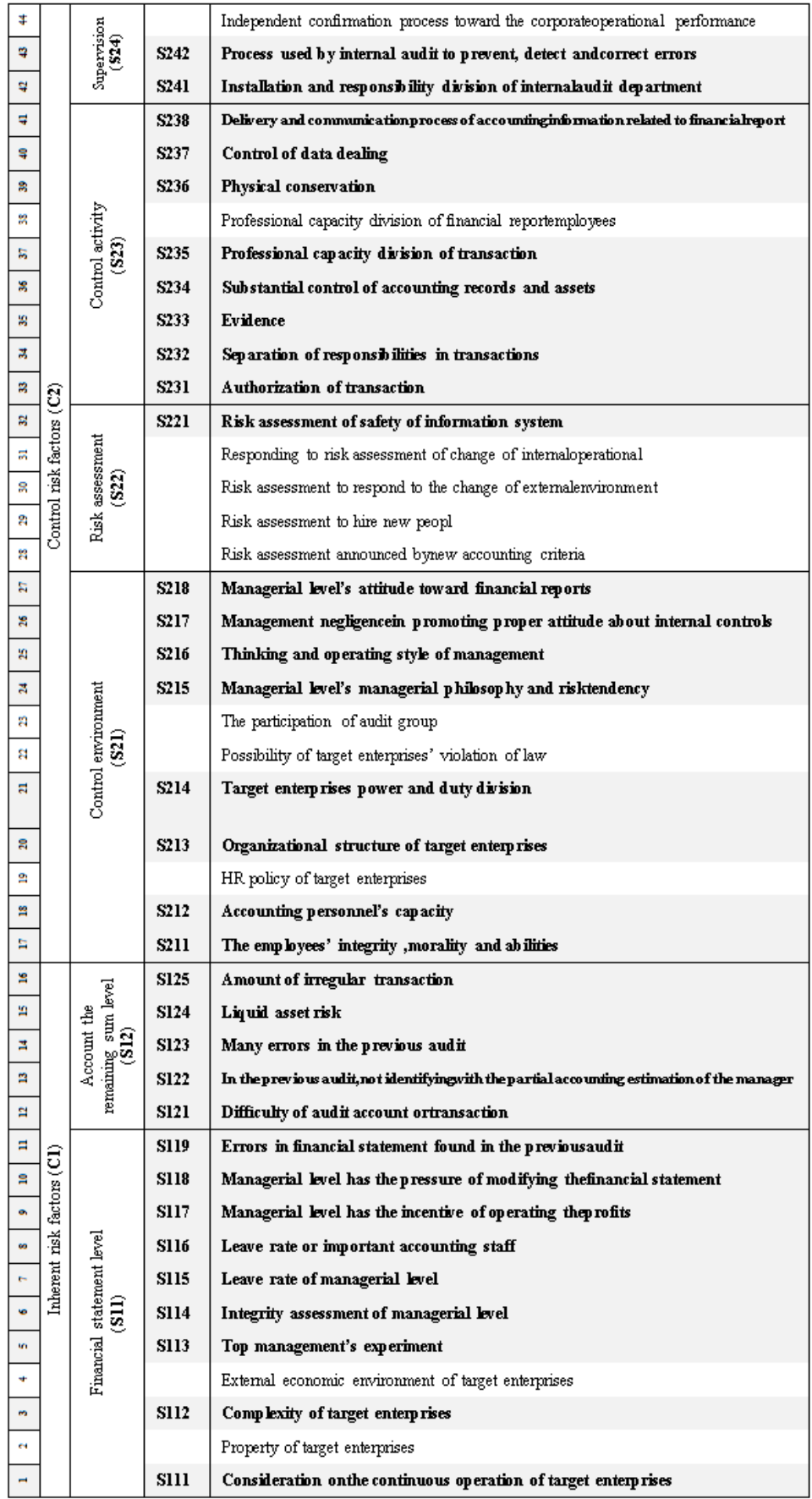

${ }^{*} \mathrm{C}$ : Criteria (Main factor), S: Sub-criteria (Secondary factor), Bold Items: Factors that are continuing to the next phase

Table 5. Potential audit risk factors affecting the second group of "Inherent risk \& Control risk

$$
\text { group" }
$$


Then, determining fuzzy means the max of the values are characterized as a crisp number. The process of assignment of fuzzy values to a numerical output value (Crisp number) is called defuzzification (Sangaiah et al., 2016). An element, in a crisp set, is either a member of the set or not.

Next, factors whose crisp points were greater than 0.70 (A rigid cut-off point) are selected as important, practical ones. Based on fuzzy screening, For Iranian auditors out of 58 factors, 40 ones were significant to be included in the next phase. Bold Items in Table 4 and 5 show the factors that are continuing to the next phase of analysis.

Thus, regarding forty extracted factors, the conceptual model of this study which is based on the combined approach of ANP-DEMATEL, has been shown for "Audit risk group" and "Inherent risk \& Control risk group" in Figures 6 and 7, respectively.

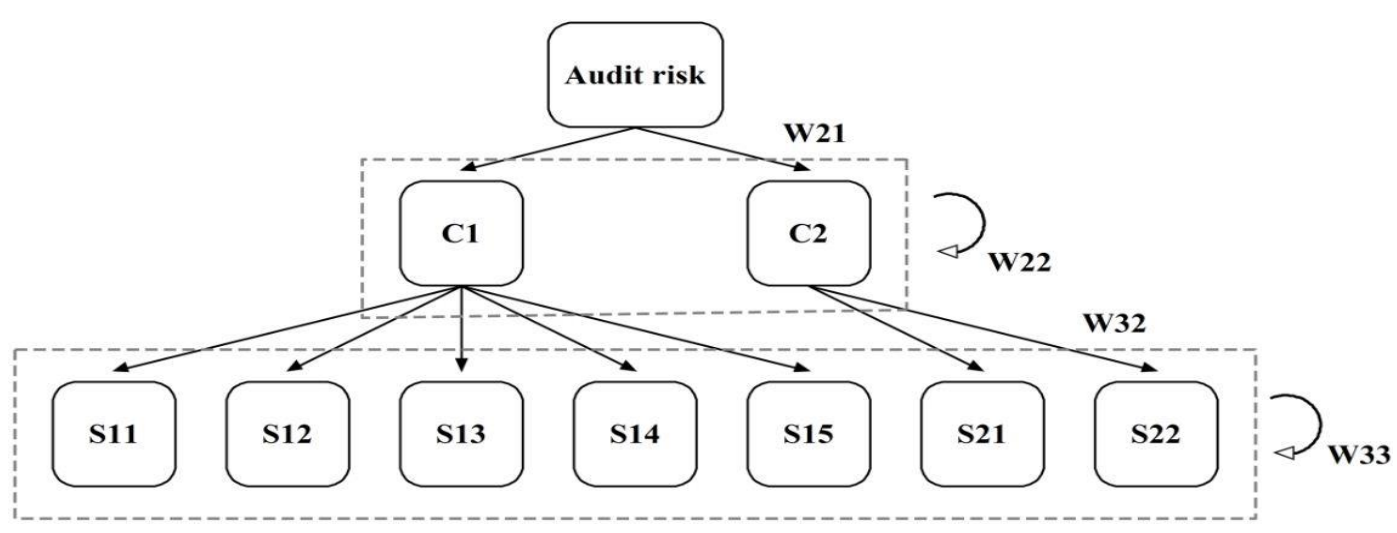

Figure 6. The conceptual model of study for the first group of "Audit risk group" considering combined ANP-DEMATEL

\subsubsection{Phases 3}

Next, as it was noted, after settling practical factors affecting the groups, the viewpoints of 15 audit experts on those factors, were collected based on the expert questionnaires (i.e. second-round of data collecting) which are special to each ANP and DEMATEL methods. 


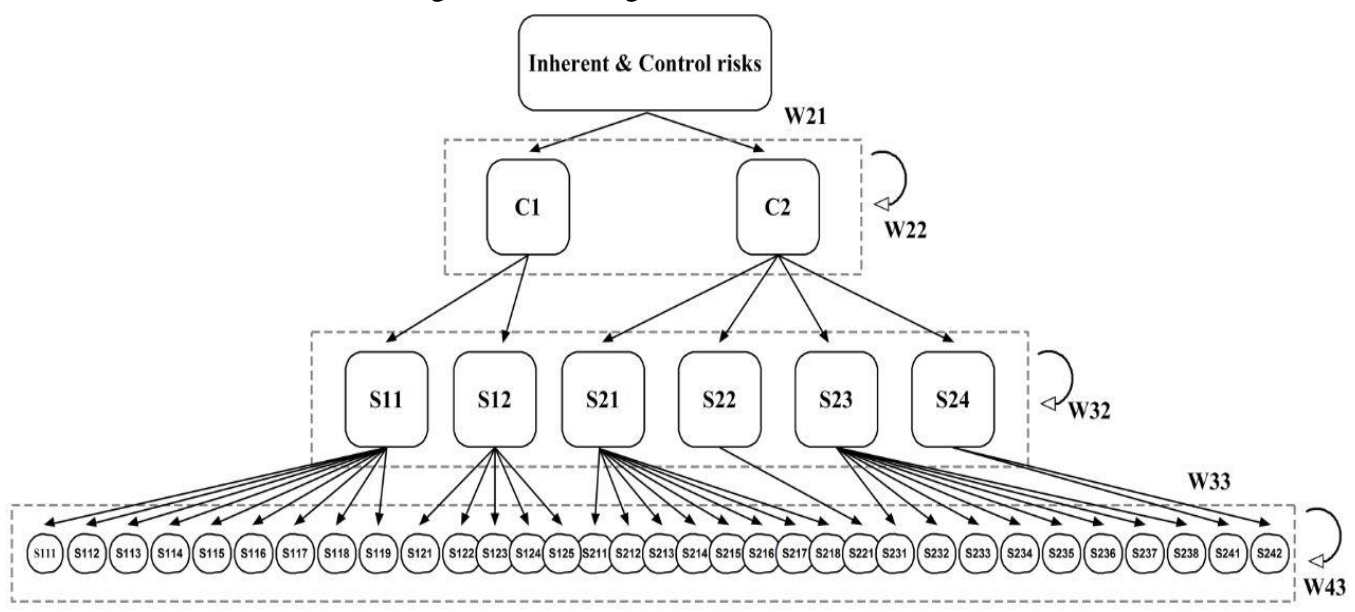

Figure 7. The conceptual model for the second group of "Inherent risk \& Control risk group" considering combined ANP-DEMATEL

The combined method is developed by using Microsoft Excel and Super Decisions software; so that initial calculation has been done using Microsoft Excel and the results including non-fuzzy numbers (crisp numbers) are manually entered to Super Decisions to calculate each factor's weight.

Determining the final priority of each factor using the Fuzzy ANP-DEMATEL approach entails the following main steps. Below, to avoid additional calculations, we only focused on the data of the group of "Audit risk group"

\subsubsection{First step: Pair-wise comparisons}

Remembering Figure 2 of the experiment process, to conduct the combined method, the ANP should be first applied. In the "Audit risk group" there were factors which should be evaluated based on 9-point evaluation scale especial to ANP questionnaire. Thus, the pairwise questionnaire of ANP handed out to 15 Iranian audit experts in order to specify their 9-point preferences of the audit risk factors in terms of audit risk model. Figure 8 shows a sample question of the first group ( $S 11, S 12, S 13, S 14, S 15, S 21$, and $S 22)$ in this round of data collecting. The participants should fill the cells inserting an appropriate number from 1 to 9 showing their preferences from equallyimportance to extremely strong.

Afterwards, data gathered should transform to the fuzzy environment. As stated by Lee et al., (2008), to deal with the uncertainty and ambiguity of the experts' 
linguistic variables, the scores of pairwise comparison were represented by triangular fuzzy numbers.

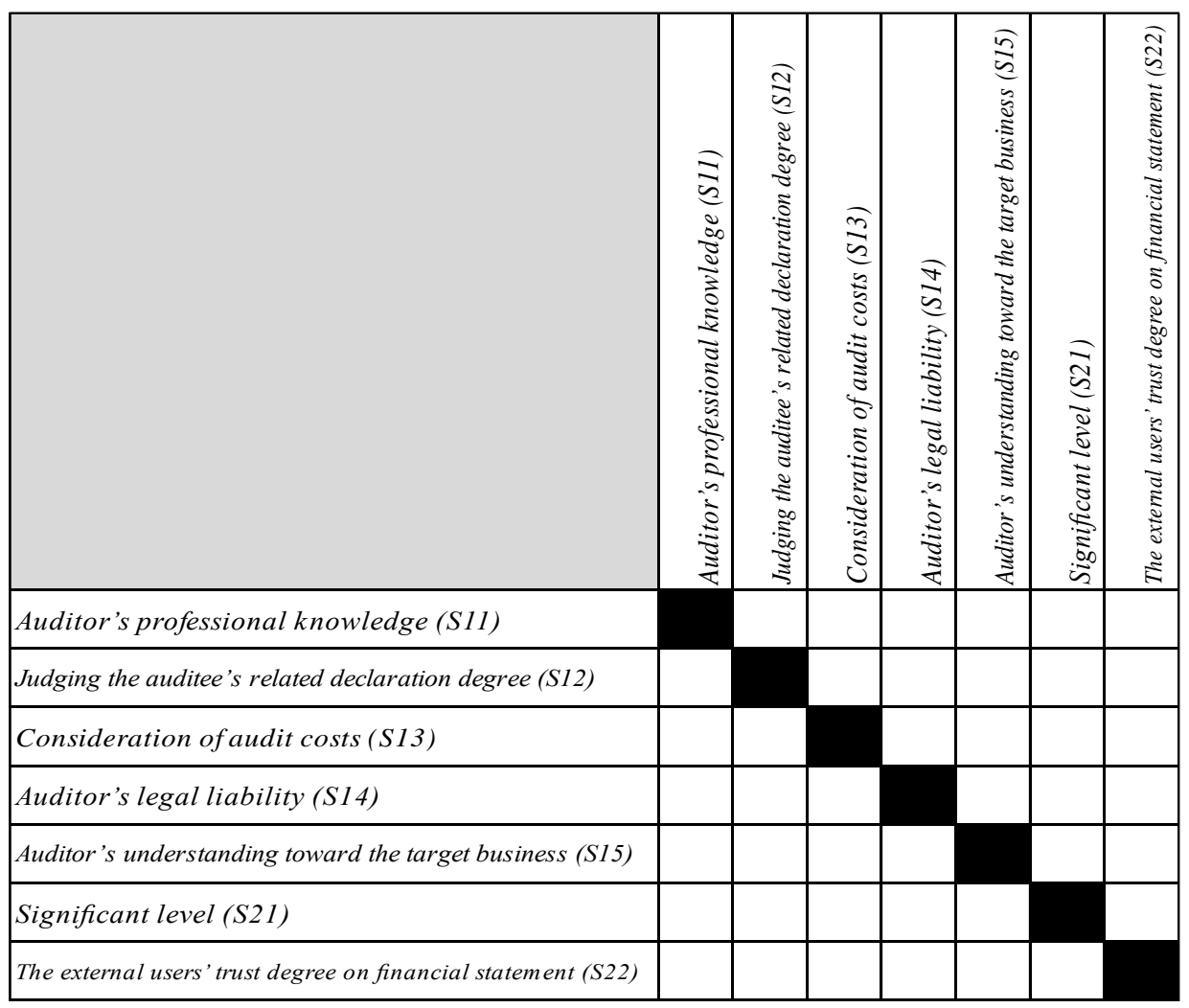

Figure 8. First step of phase 3: Sample question of the first group of "Audit risk group" in fuzzy ANP

It means, in order to fuzzify the scales pertinent to ANP, triangular membership functions are used. The membership function is used to associate a grade to each linguistic term. To ANP, the membership functions for a chosen value of $x$ transform Saaty's scale (9-point evaluation scale) into fuzzy scale.

Once the pairwise comparison matrix was established, the eigenvector had to be calculated. The eigenvector is the normal weights which are in fact the real weight of each matrix. In doing so, according to the Tzeng and Huang (2011) for each row of the pairwise comparison, matrix $S_{K}$ must be calculated using Equation (1). 
$S_{K}=\sum_{i=1}^{n} M \times\left(\sum_{i=1}^{n} \sum_{j=1}^{n} M_{g}^{j}\right)^{-1}(1)$

Then, to convert the fuzzy weights into a single crisp weight of each factor, the defuzzification process was performed. As reported by Bojadziev and Bojadziev (2007), the defuzzification method below provides a valid result (Equation 2).

$x_{\max }^{1}=\frac{l+m+u}{3} \quad x_{\max }^{2}=\frac{l+2 m+u}{4}(2) \quad x_{\max }^{3}=\frac{l+4 m+u}{6}$

(Crisp number $\left.=\mathrm{Z}^{*}=\max \left\{x_{\max }^{1}, x_{\max }^{2}, x_{\max }^{3}\right\}\right)$

The final weights of "Audit base" and "Auditee base" determining the priority of the aforementioned factors are shown in a graphic way in Figures 9 and 10.

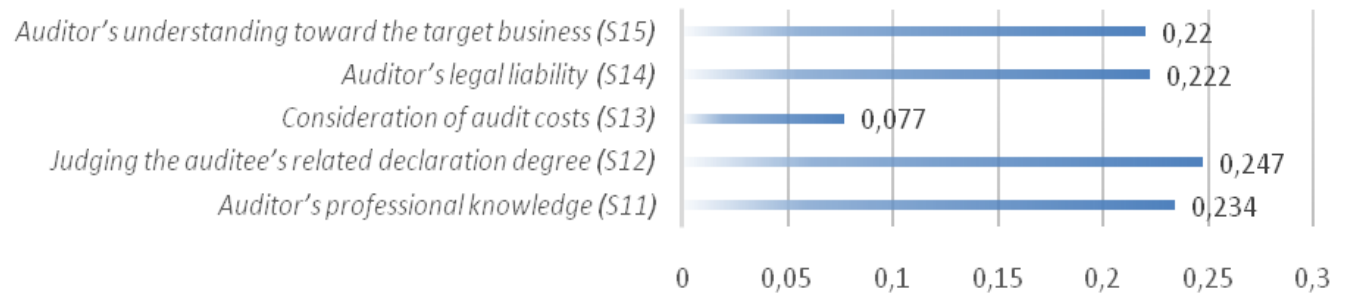

Figure 9. First step of phase 3: Final weights' main factor of Audit base (C1) of the first group of "Audit risk group" in fuzzy ANP

The external users' trust degree on financial statement (\$22)

Significantlevel (S21)

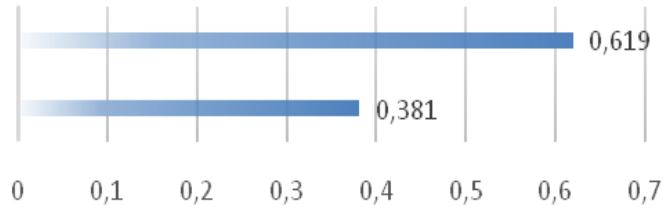

Figure 10. First step of phase 3: Final weights' main factor of Auditee base (C2) of the first group of "Audit risk group" in fuzzy ANP

3.3.3.2. Second step: Internal relations among the factors using fuzzy DEMATEL

Again, remembering Figure 5 of experiment process and also Figure 6 and 7 of the conceptual model, the next step was to calculate the internal relations 
(interdependencies) among the factors using fuzzy DEMATEL technique. The DEMATEL lodging in ANP can properly provide mutual impact and influence relationships of factors in such a way that the intensity of their effect will be determined. In doing so, the shortcoming of ANP as to interdependencies can be resolved in a satisfied manner.

Data for this step is gathered on the basis of 5-point evaluation scale especial to DEMATEL questionnaire (i.e. second-round of data collecting). Similar to ANP, the pairwise questionnaire of DEMATEL has also handed out to same 15 Iranian audit experts to specify their 5-point evaluation scale on the mutual influence of the audit risk factors from very low to very high. Figure 11 shows a sample DEMATEL question of the secondary factors of the first group (S11,S12, S21, $S 22, S 23$, and $S 24$ ) in this round of data collecting.

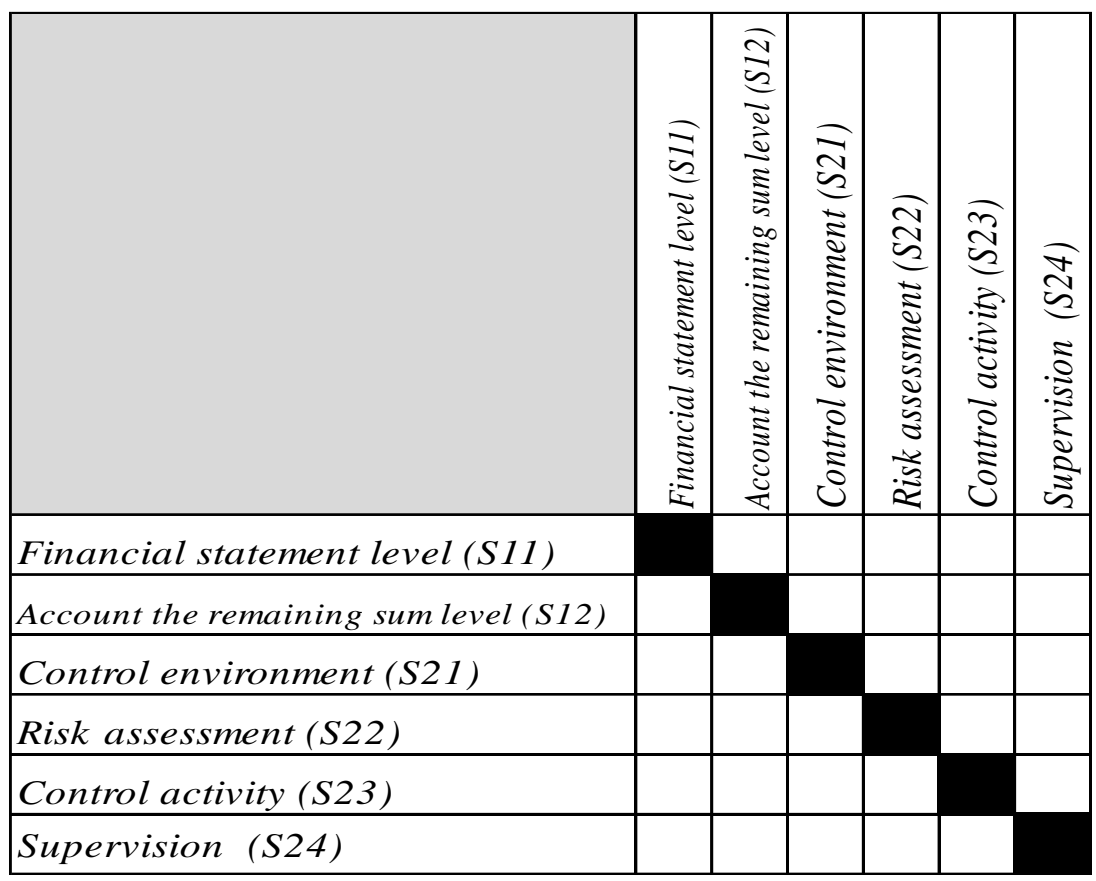

Figure 11. Second step of phase 3: Sample question of the first group of "Audit risk group" in fuzzy DEMATEL

Then, the relations among factors were investigated in a fuzzy environment to better illustrate how those relations among them were provided. In the opinion of 
Wang, et al., (2011) and Wang and Chang (1995), the fuzzy scale was first used to deal with the uncertainty and ambiguity of the experts' linguistic expressions of the 5-point scale of DEMATEL. The following stages were then performed to direct the DEMATEL technique:

\section{- Direct-relation matrix}

The direct-relation matrix is an $n \times n$ matrix denoting the degree to which the factor I affects the factor $\mathrm{j}$. In order to establish direct-relation matrix, the simple arithmetic means of fifteen audits experts`opinions were included in the calculations.

Then, the fuzzy direct-relation matrix $(\tilde{X})$ was constructed based on the aforementioned fuzzy scales.

- Fuzzy normalized direct-relation matrix

To normalize the values, $\sum \mathrm{u}_{\mathrm{ij}}$ have to be first calculated for each row. Then, the fuzzy normalized matrix $(\tilde{\mathrm{N}})$ was calculated by dividing the elements of matrix $(\tilde{\mathrm{N}})$ to the maximum value of $\sum \mathrm{u}_{\mathrm{ij}}$ (Equations (3) and (4)). Considering $(k=4.04)$ for the studied factors, Table 6 shows the fuzzy normalized direct-relation matrix.

$$
k=\max \left(\sum_{j=1}^{n} u_{i j}\right)(3) \quad \tilde{N}=\frac{1}{k} \cdot \tilde{X}(4)
$$

- Total-relation matrix $(T)$

Equation (5) was used to calculate the total-relation matrix. The total-relation matrix shows the relative degree of direct and indirect relationships between factors.

$N x(I-N)^{-1}(5)$

The fuzzy total-relation matrix $(\tilde{t})$ was then calculated using the identity matrix $\left(I_{n * n}\right)$ taking into account Equation (6).

$$
\begin{aligned}
& T_{l}=N_{l} x\left(I-N_{l}\right)^{-1} \\
& T_{m}=N_{m} x\left(I-N_{m}\right)^{-1}(6) \\
& T_{\mathbb{R}}=N_{\mathbb{R}} \times\left(I-N_{\mathbb{R}}\right)^{-1} \\
& \tilde{t}_{\mathrm{i} i \mathrm{j}}=\left(t_{\mathrm{i}, \mathrm{p}}^{\mathrm{p}}, t_{\mathrm{i} j}^{\mathrm{m}}, t_{\mathrm{ij}}^{\mathrm{n}}\right)
\end{aligned}
$$




\subsubsection{Third Step: Final priority of the criteria}

Once the previous steps are performed, we go back again to the ANP model in order to prioritize the factors. This step includes three following stages:

\section{- Unweighted supermatrix}

To determine the weights of factors, the ANP uses the supermatrix method. A supermatrix is, in fact, a partitioned matrix in which each part of the matrix shows the relationship between two levels (inner and outer relation) in the overall decision problem so that it provides a framework for determining the relative importance of the alternatives after pairwise comparisons.

\begin{tabular}{|c|c|c|c|c|c|c|c|}
\hline $\mathrm{N}$ & S11 & $\mathrm{S} 12$ & S13 & S14 & S15 & $\mathrm{S} 21$ & $\mathrm{~S} 22$ \\
\hline S11 & $\begin{array}{l}(0,0.02, \\
0.07)\end{array}$ & $\begin{array}{l}(0.14,0.19 \\
0.23)\end{array}$ & $\begin{array}{l}(0.08,0.13, \\
0.17)\end{array}$ & $\begin{array}{l}(0.07,0.11 \\
0.16)\end{array}$ & $\begin{array}{l}(0.1,0.14, \\
0.19)\end{array}$ & $\begin{array}{l}(0.08,0.12, \\
0.17)\end{array}$ & $\begin{array}{l}(0.1,0.14, \\
0.2)\end{array}$ \\
\hline $\mathrm{S} 12$ & $\begin{array}{l}(0.06,0.1 \\
0.15)\end{array}$ & $\begin{array}{l}(0,0.02, \\
0.07)\end{array}$ & $\begin{array}{l}(0.05,0.09 \\
0.14)\end{array}$ & $\begin{array}{l}(0.06,0.11 \\
0.15)\end{array}$ & $\begin{array}{l}(0.06,0.1, \\
0.15)\end{array}$ & $\begin{array}{l}(0.08,0.13 \\
0.17)\end{array}$ & $\begin{array}{l}(0.06,0.1, \\
0.15)\end{array}$ \\
\hline S13 & $\begin{array}{l}(0.02, \\
0.06,0.11)\end{array}$ & $\begin{array}{l}(0.04,0.08, \\
0.13)\end{array}$ & $\begin{array}{l}(0.01,0.03, \\
0.08)\end{array}$ & $\begin{array}{l}(0.03,0.06, \\
0.11)\end{array}$ & $\begin{array}{l}(0.08,0.12, \\
0.17)\end{array}$ & $\begin{array}{l}(0.03,0.06 \\
0.11)\end{array}$ & $\begin{array}{l}(0.04,0.08, \\
0.13)\end{array}$ \\
\hline S14 & $\begin{array}{l}(0.06,0.1 \\
0.15)\end{array}$ & $\begin{array}{l}(0.07,0.11, \\
0.16)\end{array}$ & $\begin{array}{l}(0.05,0.09 \\
0.14)\end{array}$ & $\begin{array}{l}(0,0.02, \\
0.07)\end{array}$ & $\begin{array}{l}(0.08,0.13 \\
0.17)\end{array}$ & $\begin{array}{l}(0.05,0.09 \\
0.14)\end{array}$ & $\begin{array}{l}(0.08,0.13 \\
0.17)\end{array}$ \\
\hline S15 & $\begin{array}{l}(0.07, \\
0.11,0.16)\end{array}$ & $\begin{array}{l}(0.13,0.18 \\
0.22)\end{array}$ & $\begin{array}{l}(0.12,0.16 \\
0.21)\end{array}$ & $\begin{array}{l}(0.05,0.09 \\
0.14)\end{array}$ & $\begin{array}{l}(0,0.02 \\
0.07)\end{array}$ & $\begin{array}{l}(0.07,0.11 \\
0.16)\end{array}$ & $\begin{array}{l}(0.08,0.12, \\
0.17)\end{array}$ \\
\hline $\mathrm{S} 21$ & $\begin{array}{l}(0.04, \\
0.08,0.13)\end{array}$ & $\begin{array}{l}(0.09,0.13, \\
0.18)\end{array}$ & $\begin{array}{l}(0.08,0.13, \\
0.17)\end{array}$ & $\begin{array}{l}(0.06,0.1, \\
0.15)\end{array}$ & $\begin{array}{l}(0.07,0.11 \\
0.16)\end{array}$ & $\begin{array}{l}(0,0.02, \\
0.07)\end{array}$ & $\begin{array}{l}(0.07,0.12, \\
0.17)\end{array}$ \\
\hline $\mathrm{S} 22$ & $\begin{array}{l}(0.05, \\
0.09,0.14)\end{array}$ & $\begin{array}{l}(0.05,0.09 \\
0.14)\end{array}$ & $\begin{array}{l}(0.02,0.06 \\
0.11)\end{array}$ & $\begin{array}{l}(0.06,0.1, \\
0.14)\end{array}$ & $\begin{array}{l}(0.06,0.11 \\
0.16)\end{array}$ & $\begin{array}{l}(0.06,0.11 \\
0.16)\end{array}$ & $\begin{array}{l}(0,0.02, \\
0.07)\end{array}$ \\
\hline
\end{tabular}

Table 6. Second step of phase 3: Calculation of the fuzzy normalized direct-relation matrix in fuzzy DEMATEL

Then, the matrix was defuzzified according to Bojadziev and Bojadziev (2007). Table 7 shows the defuzzified (Crisp) total-relation matrix. 


\begin{tabular}{|llllllll|}
\hline $\mathrm{T}$ & $\mathrm{S} 11$ & $\mathrm{~S} 12$ & $\mathrm{~S} 13$ & $\mathrm{~S} 14$ & $\mathrm{~S} 15$ & $\mathrm{~S} 21$ & $\mathrm{~S} 22$ \\
\hline $\mathrm{S} 11$ & 0.373 & 0.601 & 0.508 & 0.459 & 0.601 & 0.491 & 0.536 \\
$\mathrm{~S} 12$ & 0.379 & 0.384 & 0.15 & 0.389 & 0.384 & 0.427 & 0.428 \\
$\mathrm{~S} 13$ & 0.292 & 0.364 & 0.099 & 0.3 & 0.364 & 0.313 & 0.348 \\
S14 & 0.38 & 0.463 & 0.151 & 0.321 & 0.463 & 0.402 & 0.454 \\
S15 & 0.423 & 0.56 & 0.198 & 0.415 & 0.56 & 0.454 & 0.488 \\
S21 & 0.372 & 0.487 & 0.168 & 0.393 & 0.487 & 0.345 & 0.448 \\
S22 & 0.349 & 0.413 & 0.186 & 0.358 & 0.413 & 0.384 & 0.332 \\
\hline
\end{tabular}

Table 7. Second step of phase 3: Defuzzified (Crisp) total-relation matrix in fuzzy DEMATEL

Calling on Figure 3 of difference between a hierarchy and a network, the initial supermatrix below theoretically displays what subsequently the DEMATEL's results were inserted in.

$$
W=\left(\begin{array}{ccc}
0 & 0 & 0 \\
w_{21} & w_{22} & 0 \\
0 & w_{32} & I
\end{array}\right)
$$

- Weighted supermatrix

In the next stage, the unweighted supermatrix was weighted and then normalized. Zero entries in weighted matrix indicate that there are no relationships between the components (Shafiee et al., 2014). Also, the sum of the elements in each column, in the weighted supermatrix, is equal to 1 (Table 8).

\section{- Limit supermatrix}

The limit supermatrix estimates the final weight of each factor. It was calculated by the exponentiation of all elements of the weighted supermatrix (Table 9). Thisis iterated until all elements of the weighted supermatrix become the same (i.e. convergence). Here, all elements would be zero, and only the elements belong to sub-criteria is a value repeated in each row. Finally, regarding all aforementioned phases, for "Audit risk group", the final Prioritization of factors was provided as shown in Figure 12. 


\begin{tabular}{|c|c|c|c|c|c|c|c|c|c|c|c|}
\hline & & Purpose & \multicolumn{2}{|c|}{ Criteria } & \multicolumn{7}{|c|}{ Sub-criteria } \\
\hline & & Purpose & $\mathrm{C} 1$ & $\mathrm{C} 2$ & S11 & $\mathrm{S} 12$ & S13 & S14 & S15 & $\mathrm{S} 21$ & $\mathrm{~S} 22$ \\
\hline Goal & Purpose & 0 & 0 & 0 & 0 & 0 & 0 & 0 & 0 & 0 & 0 \\
\hline \multirow{2}{*}{ Criteria } & $\mathrm{C} 1$ & 0.4 & 0.229 & 0.344 & 0 & 0 & 0 & 0 & 0 & 0 & 0 \\
\hline & $\mathrm{C} 2$ & 0.6 & 0.363 & 0.237 & 0 & 0 & 0 & 0 & 0 & 0 & 0 \\
\hline \multirow{7}{*}{$\begin{array}{c}\text { Sub- } \\
\text { criteria }\end{array}$} & $\mathrm{S} 11$ & 0 & 0.096 & 0 & 0.145 & 0.184 & 0.348 & 0.174 & 0.184 & 0.174 & 0.177 \\
\hline & $\mathrm{S} 12$ & 0 & 0.101 & 0 & 0.148 & 0.117 & 0.103 & 0.148 & 0.117 & 0.152 & 0.141 \\
\hline & S13 & 0 & 0.031 & 0 & 0.114 & 0.111 & 0.068 & 0.114 & 0.111 & 0.111 & 0.115 \\
\hline & S14 & 0 & 0.091 & 0 & 0.148 & 0.142 & 0.104 & 0.122 & 0.142 & 0.143 & 0.15 \\
\hline & S15 & 0 & 0.09 & 0 & 0.165 & 0.171 & 0.136 & 0.157 & 0.171 & 0.161 & 0.161 \\
\hline & S21 & 0 & 0 & 0.16 & 0.145 & 0.149 & 0.115 & 0.149 & 0.149 & 0.123 & 0.148 \\
\hline & $\mathrm{S} 22$ & 0 & 0 & 0.259 & 0.136 & 0.126 & 0.127 & 0.136 & 0.126 & 0.136 & 0.11 \\
\hline
\end{tabular}

Table 8. Third step of phase 3: Weighted supermatrix in combined fuzzy ANP-DEMATEL approach

\begin{tabular}{|c|c|c|c|c|c|c|c|c|c|c|c|}
\hline & & Purpose & & eria & & & & b-Crite & & & \\
\hline & & Purpose & $\mathrm{C} 1$ & $\mathrm{C} 2$ & S11 & $\mathrm{S} 12$ & $\mathrm{~S} 13$ & S14 & S15 & $\mathrm{S} 21$ & $\mathrm{~S} 22$ \\
\hline Purpose & Purpose & 0 & 0 & 0 & 0 & 0 & 0 & 0 & 0 & 0 & 0 \\
\hline \multirow{2}{*}{ Criteria } & $\mathrm{C} 1$ & 0 & 0 & 0 & 0 & 0 & 0 & 0 & 0 & 0 & 0 \\
\hline & $\mathrm{C} 2$ & 0 & 0 & 0 & 0 & 0 & 0 & 0 & 0 & 0 & 0 \\
\hline \multirow{3}{*}{ Sub-Criteria } & S11 & 0.206 & 0.206 & 0.206 & 0.206 & 0.206 & 0.206 & 0.206 & 0.206 & 0.206 & 0.206 \\
\hline & S12 & 0.145 & 0.145 & 0.145 & 0.145 & 0.145 & 0.145 & 0.145 & 0.145 & 0.145 & 0.145 \\
\hline & S13 & 0.105 & 0.105 & 0.105 & 0.105 & 0.105 & 0.105 & 0.105 & 0.105 & 0.105 & 0.105 \\
\hline
\end{tabular}




\begin{tabular}{|c|c|c|c|c|c|c|c|c|c|c|c|}
\hline & S14 & 0.134 & 0.134 & 0.134 & 0.134 & 0.134 & 0.134 & 0.134 & 0.134 & 0.134 & 0.134 \\
\hline & S15 & 0.153 & 0.153 & 0.153 & 0.153 & 0.153 & 0.153 & 0.153 & 0.153 & 0.153 & 0.153 \\
\hline & S21 & 0.133 & 0.133 & 0.133 & 0.133 & 0.133 & 0.133 & 0.133 & 0.133 & 0.133 & 0.133 \\
\cline { 2 - 13 } & S22 & 0.123 & 0.123 & 0.123 & 0.123 & 0.123 & 0.123 & 0.123 & 0.123 & 0.123 & 0.123 \\
\hline
\end{tabular}

Table 9. Third step of phase 3: Limit supermatrix in combined fuzzy ANP-DEMATEL approach

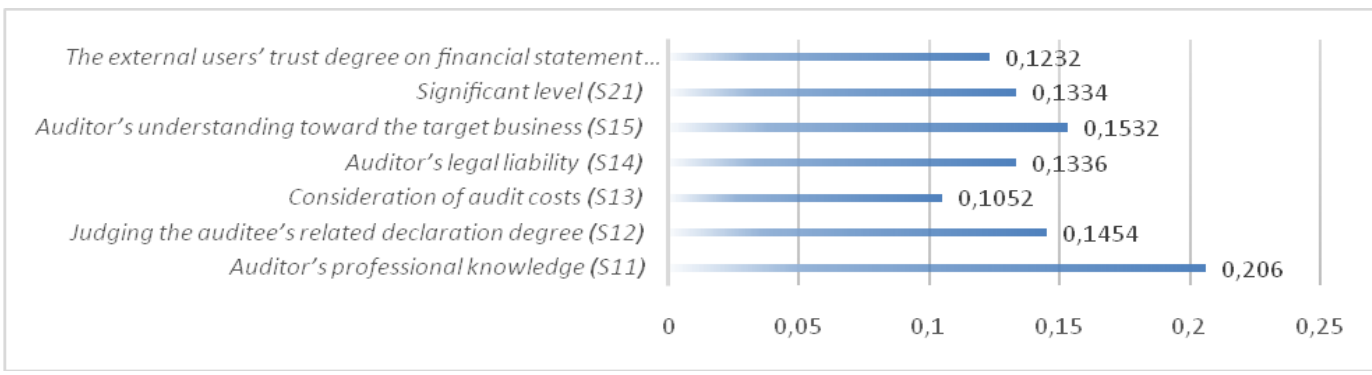

Figure 12. Final results of "Audit risk group"

\section{RESEARCH FINDINGS}

According to the final results, the proposed combined model prioritized the factors influencing the first group of "Audit risk group" factors by their weights (Table 10). The results show that when one considers the internal relations of variables of the study, the significance level and rank of indicators of the study will be changed (Figures 9, 10, 11). To "Audit risk group", the "Auditor's professional knowledge" belonging to audit base main factor with the highest weight (0.206) provided the first position."Auditor understands towards the target business" (0.153) and "Judging the auditee's related declaration degree" (0.145), which both factors are belonging to Audit base main factor, found the subsequent positions. However, as believed by Iranian auditors, "The external users' trust degree on financial statement" was introduced as the lowest priority. Likewise, it seems that regarding the fourth position of "Auditor's legal liability" (0.133), the factor which added to the Chang et al., (2008) criteria regarding Iranian audit experts, CPAs are of the opinion that this factor plays a mediocre role in estimating the audit risk in Iran. Meanwhile, "Consideration of audit costs", as it was expected, found the last position because audit costs of an audit project are not a significant factor among others for Iranian auditors in assessment audit risk. 
Regarding the results of the first group, it is generally reasoned that auditor related factors have a further influence on the accurate assessment of audit risk in the Iranian professional auditing environment.

In the "Inherent risk \& control risk" group, (Table 11) "Process used by internal audit to prevent, detect and correct errors" factor, belonging to Supervision main factor (and Control risk) with the highest weight (0.0495) has the first grade. The second and third rankings of this group are related to "Authorization of transaction", belonging to Control activity main factor (and Control risk) with the weight of 0.0446 and "Installation and responsibility division of internal audit department", belonging to Supervision main factor (and Control risk) with a weight of 0.0283 , respectively. Therefore, according to the Iranian auditors, Supervision main factor is a determining factor in estimating audit risk. Thus, companies' self-control can decline considerably the audit risk in Iranian professional environment. Likewise, since the three first factors are relevant to Control risk, thus, it can be concluded that Control risk is a more significant factor compared to the Inherent risk in assessing audit risk. In contrast, it seems that since "Control of data dealing" factor is in the last position, it cannot play a deciding share in estimating audit risk in Iran. Therefore, for Iranian auditors, precise assessment of audit risk in the Iranian professional environment entails paying attention to two general factors including Audit base factors and Supervision factors. Also, factors added to the Chang and his colleagues (2008) by authors including "Management negligence in promoting proper attitude about internal controls", "Evidence" and, "Physical conservation" take positions of 20, 28 and 32 respectively; indicating having less importance to Iranian auditors to assess audit risk.

\begin{tabular}{|c|c|c|c|c|}
\hline Label & Secondary Audit risk factor & Weight & Rank & Main factor \\
\hline$S 11$ & Auditor's professional knowledge & 0.2060 & 1 & \multirow[t]{4}{*}{ Audit base } \\
\hline$S 12$ & Judging the auditee's related declaration degree & 0.1454 & 3 & \\
\hline$S 13$ & Consideration of audit costs & 0.1052 & 7 & \\
\hline S14 & Auditor's legal liability & 0.1336 & 4 & \\
\hline
\end{tabular}




\begin{tabular}{|l|l|l|l|l|}
\hline S15 & Auditor's understanding toward the target business & $\mathbf{0 . 1 5 3 2}$ & $\mathbf{2}$ & \\
\hline S21 & Significant level & 0.1334 & 5 & Auditee base \\
\hline S22 & The external users' trust degree on financial statement & 0.1232 & 6 & \\
\hline
\end{tabular}

Table 10. Prioritizing weighted factors of first group of "Audit risk group" based on proposed approach

\begin{tabular}{|c|c|c|c|c|}
\hline Label & Secondary inherent risk \& control risk factors & Weight & Rank & $\begin{array}{l}\text { Main } \\
\text { factor }\end{array}$ \\
\hline$S 111$ & Consideration on the continuous operation of target enterprises & 0.0105 & 17 & \multirow{14}{*}{$\begin{array}{l}\text { Inherent } \\
\text { risk }\end{array}$} \\
\hline S112 & Complexity of target enterprises & 0.0108 & 15 & \\
\hline$S 113$ & Top management's experiment & 0.0076 & 23 & \\
\hline S114 & Integrity assessment of managerial level & 0.0175 & 5 & \\
\hline S115 & Leave rate of managerial level & 0.0103 & 19 & \\
\hline S116 & Leave rate or important accounting staff & 0.0072 & 25 & \\
\hline S117 & Managerial level has the incentive of operating the profits & 0.014 & 10 & \\
\hline$S 118$ & $\begin{array}{l}\text { Managerial level has the pressure of modifying the financial } \\
\text { statement }\end{array}$ & 0.0137 & 11 & \\
\hline$S 119$ & Errors in financial statement found in the previous audit & 0.0142 & 9 & \\
\hline$S 121$ & Difficulty of audit account or transaction & 0.0148 & 8 & \\
\hline$S 122$ & $\begin{array}{l}\text { In the previous audit, not identifying with the partial accounting } \\
\text { estimation of the manager }\end{array}$ & 0.0119 & 12 & \\
\hline$S 123$ & Many errors in the previous audit & 0.0162 & 6 & \\
\hline$S 124$ & Liquid asset risk & 0.0148 & 7 & \\
\hline S125 & Amount of irregular transaction & 0.0262 & 4 & \\
\hline
\end{tabular}




\begin{tabular}{|c|c|c|c|c|}
\hline$S 211$ & The employees' integrity, morality and abilities & 0.0107 & 16 & \multirow{18}{*}{$\begin{array}{l}\text { Control } \\
\text { risk }\end{array}$} \\
\hline$S 212$ & Accounting personnel's capacity & 0.0104 & 18 & \\
\hline$S 213$ & Organizational structure of target enterprises & 0.0079 & 22 & \\
\hline$S 214$ & Target enterprises power and duty division & 0.0086 & 21 & \\
\hline$S 215$ & Managerial level's managerial philosophy and risk tendency & 0.0109 & 14 & \\
\hline$S 216$ & Thinking and operating style of management & 0.0114 & 13 & \\
\hline$S 217$ & $\begin{array}{l}\text { Management negligence in promoting proper attitude about } \\
\text { internal controls }\end{array}$ & 0.0098 & 20 & \\
\hline$S 218$ & Managerial level's attitude toward financial reports & 0.0072 & 26 & \\
\hline$S 231$ & Authorization of transaction & 0.0446 & 2 & \\
\hline$S 232$ & Separation of responsibilities in transactions & 0.0075 & 24 & \\
\hline$S 233$ & Evidence & 0.0067 & 27 & \\
\hline$S 234$ & Substantial control of accounting records and assets & 0.0057 & 29 & \\
\hline$S 235$ & Professional capacity division of transaction & 0.0057 & 30 & \\
\hline$S 236$ & Physical conservation & 0.0057 & 31 & \\
\hline$S 237$ & Control of data dealing & 0.0057 & 32 & \\
\hline$S 238$ & $\begin{array}{l}\text { Delivery and communication process of accounting information } \\
\text { related to financial report }\end{array}$ & 0.0057 & 28 & \\
\hline$S 241$ & $\begin{array}{l}\text { Installation and responsibility division of internal audit } \\
\text { department }\end{array}$ & $\mathbf{0 . 0 2 8 3}$ & 3 & \\
\hline$S 242$ & $\begin{array}{l}\text { Process used by internal audit to prevent, detect and correct } \\
\text { errors }\end{array}$ & 0.0495 & 1 & \\
\hline
\end{tabular}

Table11. Prioritizing weighted factors of second group of "Inherent risk \& control risk group" based on proposed approach 


\section{CONCLUSIONS}

Proper detection risk assessment would positively affect audit strategies and the results of the audit. Through assessing of the acceptable audit risk level, inherent risk, and control risk, auditors evaluate the degree of detection risk. Considering audit risk model, the result of the audit is influenced by the audit evidence and its amount which depends on the degree of detection risk (Chang et al., 2008). It means auditors should adjust their auditing process by assessing the risks of material misstatement in financial statements and concentrate on more risky positions.

If an auditor overestimates the audit risk, then the auditing process will be implemented more than needed which in return decreases the efficiency of auditing and wastes resources. On the other hand, if she or he underestimates it, the risk of audit failure can be increased which not only leaves the risk of lawsuits but also gradually declines the economic value of auditing in the longtime period (Beatie et al., 2002). Therefore, the accuracy of risk assessment by auditors influences directly efficiency and effectiveness of audit.

In the audit risk model, there are factors related to audit risk components each one may affect detection risk degree and thus finally the amount of audit evidence collected and size of samples. Thus, to identify more influencing and objective factors through a detailed process could reduce the risk of audit failure and universally result in more audit quality.

However, each contributing audit risk factors may influence or be influenced by other ones and has interdependencies with various degrees. Thus, "In arriving at an evaluation of each audit risk components the auditor will usually have to consider factors which may influence those components; these require the auditor to assess the importance of each factor and consider any interdependencies that exist between them." (Sherer and Turley, 1997).

Again, audit risk factors, in the risk-based audit manuals which are proposed by the professional authorities and applied in practice, are considered independently in audit risk assessment. 
Although some researchers have pointed out that relationships are likely to exist among audit risk individual's components, they have not experienced the inner and outer dependencies among factors affecting those components.

According to the report by PCAOB (2015), the audit firms have encouraged to consider deficiencies related to the risk assessment. The suggested example of remedial actions has included considering impounding modern analytical methods (Kuenkaikaew and Vasarhelyi, 2013). Given the limitations of the audit risk model and thus current audit decision-making process, we develop a case study of using a fuzzy multi-criteria decision support framework in assessing audit risk to provide an in-depth understanding of the factors involved in.

Considering Chang et al., (2008) and some audit experts' views, we first organized total critical risk factors influencing detection risk assessment. Using a fuzzy screening method to reduce the less important, practical factors, we then classified the factors into "Audit risk group" and "Inherent risk \& control risk group". Next, fuzzy ANP-DEMATEL approach was applied separately for each group to weight and then prioritize influencing factors of audit risk model considering their interdependencies.

The results show, according to Iranian CPAs, factors of Auditor's professional knowledge, Judging the auditee's related declaration degree, and Auditor's understanding toward the target business take the first three position in the "Audit risk group", respectively. Also, CPAs are of the opinion that in the second group of "Inherent risk \& control risk group" factors including Process used by internal audit to prevent, detect and correct errors, Authorization of transaction, and Installation and responsibility division of internal audit department have more important position the audit risk model context.

Noted that many studies related to ANP-DEMATEL involve using this approach to choose among alternatives or an evaluation of, say, management systems, products, suppliers, websites, etc., however, the objective of this study is not necessarily a ranking of choices, as in many ANP-DEMATEL studies, but an intermediate result means weighting of audit risk factors. 
The combined fuzzy ANP and fuzzy DEMATEL approach used in this study provides a more correct, precise weight for each factor can explore alternative, more rigorous framework for decision making in risk assessment by integrating interdependent relationships within and among audit risk factors. Those weights can be used effectively in designing audit risk model; so that factors with more weight have more effect and those with little have less on assessing of detection risk degree. For example, to assess control risk, we would consider the evaluated weights of influencing factors in order to calculate the real coefficient of each factor in assessing detection risk. The more objective detection risk assessment, the better the understanding of evidence and the less risk of audit failure.

Although the study has reached its aim, some limitations should be noted. In this work, we consider the Iranian CPAs as case study to evaluate the proposed model in terms of its feasibility and practical issues. The audit risk is a subject that is mostly influenced by the environment, conditions, rules and other features of the audit operation. Logically, influenced by such situations, the factors that may affect the audit risk would vary in different regulatory, legal, and business practices. Thus, for the results of the paper are basically depending on the opinion of the certain participants, the results, for sure, could differ from those of other environments. Although we believe the localized influencing factors assessed by the proposed model can take part in a more objective detection risk assessment, the results of the paper are depending on the opinion of the certain participants. Moreover, Regarding total number of involving factors, the pairwise comparisons would be burdensome and may in some cases result in less concentration although to avoid side effects of the process, we had to make it easy for participants by considering an MS EXCEL based questionnaire, giving them rational response time, sending regularly proper notifications, and offering an incentive of sending final results of the paper. Finally, the proposed model is a complex methodology and requires more efforts especially in the practical context. This provides a good starting point for further research. Developing, for example, an MS Excel spreadsheet-based decision support system makes it possible for the auditors to enter their own factors using the program and having correct weight of them. The developed system can be easy to use and serve as a practical guiding framework in different regulatory, legal, and business practices. Also, while keeping the 
proposed framework, to follow the methodology within particular industries, or within particular sectors of the business world will result in specific audit risk factors for the same environment; thus would be employed by official bodies and/or audit firms in order to coding new standards and/or audit manuals relying on the certain factors.

There are also further points that can be included. To investigate other integrated MCDM method with DEMATEL, ANP, and TOPSIS in a fuzzy environment is a desirable for future work. We also suggest using other potential audit risk factors (criteria and sub-criteria) into the model. Moreover, considering the proposed model in other accounting and audit aspects especially in decision-making context might provide an important area for future research.

\section{Acknowledgment}

We would like to show our gratitude to Dr. Roger Debreceny for his invaluable supports and Dr. David Wang for resourceful comments on an earlier version of the manuscript although any errors are our own and should not tarnish the reputations of these esteemed persons. 


\section{REFERENCES}

ALTINTAS, M.; ERGINEL, N.; KUCUK, G. (2016): "Determining the Criteria and Evaluating Six Sigma Projects via Fuzzy ANP method in Group Decision”, IFAC-Papers OnLine, vol. 49, n. 12:1850-1855. https://doi.org/10.1016 /j.ifacol.2016.07. 852

ALTUNTAS, S.; SELIM, H.; DERELI, T. (2014) :“A fuzzy DEMATEL-based solution approach for facility layout problem: a case study", The International Journal of Advanced Manufacturing Technology, vol. 73, n. 5-8: 749-771 https://doi.org/10.1007/s00170-014-5826-3

AICPA (1983): SAS: Audit Risk and Materiality in Conducting an Audit. American Institute of Certified Public Accountants, New York.

AICPA (1981): SAS Audit Sampling. American Institute of Certified Public Accountants, New York

ARENS, A. A.; ELDER, R. J.; BEASLEY, M. S.; JENKINS, G. J. (2005): Auditing and assurance services: an integrated approach. Pearson/Prentice Hall.

BAYAZIT, O. (2006): "Use of analytic network process in vendor selectiondecisions", Benchmarking: An International Journal, vol. 13, n.5: 566579.https://doi.org/10.1108/14635770610690410

BEASLEY, M. S.; CARCELLO, J. V.; HERMANSON, D. R. (2001): “Top 10 audit deficiencies", Journal of Accountancy, vol. 191, n. 4: 63.

BEATIE, V.; FEARNLEY, S.; BRANDT, R. (2002): "Auditor Independence and Audit Risk in the UK: A Reconceptualisation", Retrieved from the University of Stirling, http://www.stir.ac.uk/

BEDARD, J. C.; GRAHAM, L. E. (2002): "The effects of decision aid orientation on risk factor identification and audit test planning", Auditing: A Journal of Practice \& Theory, vol. 21, n.2: 39-56. https://doi.org/10.2308/aud.2002.21.2.39

BOJADZIEV, G.; BOJADZIEV, M. (2007): Fuzzy logic for business, finance, and management. World Scientific Publishing Co., Inc.

BULYGA, R. P.; GISIN, V. B.; VOLKOVA, E. S. (2016): "Multivalued logic in audit risk assessment", In Soft Computing and Measurements (SCM)", Paper 
presented at the XIX IEEE International Conference. https://doi. org/10.1109/scm.2016. 7519833

BÜYÜKÖZKAN, G.; ÇIFÇI, G. (2012): “A novel hybrid MCDM approach based on fuzzy DEMATEL, fuzzy ANP and fuzzy TOPSIS to evaluate green suppliers", Expert Systems with Applications, vol. 39, n.3: 3000-3011. https://doi.org/ 10.1016/j.eswa.2011.08.162

CARLSSON, C.; FULLÉR, R. (1995): “On fuzzy screening systems”, InProc. 3rd European Congress on Intelligent Technologies and Soft Computing, Aachen. https://doi.org/10.1007/978-94-011-2014-2_24

CHANG, B.; CHANG, C. W.; WU, C. H. (2011): "Fuzzy DEMATEL method for developing supplier selection criteria", Expert systems with Applications, vol. 38, no.3: 1850-1858.https://doi.org/10.1016/j.eswa.2010.07.114

CHANG, S. I.; TSAI, C. F.; SHIH, D. H.; HWANG, C. L. (2008): "The development of audit detection risk assessment system: Using the fuzzy theory and audit risk model", Expert Systems with applications, vol. 35, n. 3: 10531067.https://doi.org/10.1016/j.eswa.2007.08.057

CHENG, E. W.; LI, H. (2004): "Contractor selection using the analytic network process", Construction management and Economics, vol. 22, n. 10: 1021-1032. https://doi.org/10.1080/0144619042000202852

COMUNALE, C. L.; ROSNER, R. L.; SEXTON, T. R. (2010): “The auditor's assessment of fraud risk: A fuzzy logic approach”, Journal of Forensic \& Investigative Accounting, vol. 3, n. 1: 149-194.

COSO (1996): Committee of Sponsoring Organizations of the Treadway Commission. https://www.coso.org/Pages/default.aspx

DAĞDEVIREN, M.; YÜKSEL, İ.; KURT, M. (2008): “A fuzzy analytic network process (ANP) model to identify faulty behavior risk (FBR) in work system", Safety Science, vol. 46, n. 5: 771-783.https://doi.org/10.1016/j.ssci.2007.02.002

DUSENBURY, R. B.; REIMERS, J. L.; WHEELER, S. W. (2000): "The audit risk model: An empirical test for conditional dependencies among assessed component risks", Auditing: A Journal of Practice \& Theory, vol. 19 , n. 2: 105117.https://doi.org/10.2308/aud.2000.19.2.105 
DUTTA, S. K.; SRIVASTAVA, R. P.; KRISHNAMOORTHY, G.; LOEBBECKE, J. K. (1993): "Aggregation of evidence in auditing: A likelihood perspective; Discussion”, Auditing, vol. 12, 137.

FRIEDLOB, G. T.; SCHLEIFER, L. (1999): "Fuzzy logic: application for audit risk and uncertainty", Managerial Auditing Journal, vol. 14, n. 3: 127- 137. https://doi.org/10.1108/02686909910259103

GENCER, C.; GÜRPINAR, D. (2007): “Analytic network process in supplier selection: A case study in an electronic firm", Applied mathematical modelling, vol. 31, n. 11: 2475-2486.https://doi.org/10.1016/j.apm.2006.10.002

GHORABAEE, M. K. (2016): "Developing an MCDM method for robot selection with interval type-2 fuzzy sets", Robotics and Computer-Integrated Manufacturing, vol. 37: 221-232. https://doi.org/10.1016/j.rcim.2015.04.007

GRAMLING, A.; RITTENBERG, L. E.; JOHNSTONE, K. M. (2011): Auditing A Business Risk Approach. 8th Edition. South-Western Cengage Learning.

HARRISON, K.; SRIVASTAVA, R.P.; PLUMLEE, R. D. (2002): “Auditors' Evaluations of Uncertain Audit Evidence: Belief Functions versus Probabilities", in Belief Functions in Business Decisions, edited by R. P. Srivastava and T. Mock, Physica-Verlag, Heidelberg, Springer-Verlag Company. https://doi.org/10. 1007/978-3-7908-1798-0_6

HAYES, R.; DASSEN, R.; SCHILDER, A.; WALLAGE, P. (2005): Principles of Auditing: An Introduction to International Standards on Auditing, ( $2^{\text {nd }}$ ed.). England: Prentice-Hall.

HELLIAR, C.; LYON, B.; MONROE, G. S.; NG, J.; WOODLIFF, D. R. (1996): "UK Auditors' perceptions of Inherent Risk", The British Accounting Review, vol. 28, n. 1: 45-72.https://doi.org/10.1006/bare.1996.0003

HUANG, B.; HU, Z. J.; ZHOU, X. Z. (2009): "Dominance relation-based fuzzyrough model and its application to audit risk evaluation", Control and Decision, vol. 24, n. 6: 899-902.

IMONIANA, J. O.; GARTNER, I. R. (2008): "Towards a Multi-Criteria Approach to Corporate Auditing Risk Assessment in Brazilian Context". https://doi.org/10.2139/ssrn.1095950 
INTERNATIONAL FEDERATION OF ACCOUNTANTS (IFAC), ISA (2009) 200:Overall objectives of the independent auditor and the conduct of an audit in accordance with international standards on auditing.

IRANIAN AUDIT ORGANIZATION (2000). Iranian Audit manual: partially revised to include audit risk management, Tehran, Iran: Audit Organization.

JANKÛNAITË, R.; KAANAPICKIENE, R.; GIPIENË, G. (2005): “Employment of Audit Risk Models", Ekonomika, vol. 71: 1-18.

KABAK, M. (2013): “A Fuzzy DEMATEL-ANP Based Multi Criteria Decision Making Approach for Personnel Selection”, Journal of Multiple-Valued Logic \& Soft Computing, vol. 20, n. 5/6: 571-593.

KHAN, M. A.; ANSARI, A. Q. (2012): "Handbook of Research on Industrial Informatics and Manufacturing Intelligence: Innovations and Solutions". IGI Global. https://doi.org/10.4018/978-1-46660-294-6

KHURANA, I. K.; RAMAN, K. K. (2004): "Litigation risk and the financial reporting credibility of Big 4 versus non-Big 4 audits: Evidence from AngloAmerican countries", The Accounting Review, vol. 79, n. 2: 473-495. https://doi.org/10.2308/accr.2004.79.2.473

KRISHNAN, J.; KRISHNAN, J. (1997): "Litigation risk and auditor resignations", Accounting review, vol. 72: 539-560.

KUENKAIKAEW, S.; VASARHELYI, M. A. (2013): "The predictive audit framework", The International Journal of Digital Accounting Research, Vol. 13: 37-71. https://doi.org/10.4192/1577-8517-v13_2

KUMRU, M.; KUMRU, P. Y. (2015): “A fuzzy ANP model for the selection of 3D coordinate-measuring machine", Journal of Intelligent Manufacturing, vol. 26, n. 5: 999-1010. https://doi.org/10.1007/s10845-014-0882-y

LEE, A. H.; CHEN, W. C.; CHANG, C. J. (2008): “A fuzzy AHP and BSC approach for evaluating performance of IT department in the manufacturing industry in Taiwan", Expert systems with applications, vol. 34, n. 1: 96-107. https://doi.org/10.1016/j.eswa.2006.08.022

LEE, W. S.; HUANG, A. Y.; CHANG, Y. Y.; CHENG, C. M. (2011): “Analysis of decision making factors for equity investment by DEMATEL and Analytic 
Network Process", Expert Systems with Applications, vol. 38, n. 7: 8375-8383. https://doi.org/10.1016/j.eswa.2011.01.027

LIN, R. J. (2013): "Using fuzzy DEMATEL to evaluate the green supply chain management practices", Journal of Cleaner Production, vol. 40: 32-39. https://doi.org/10.1016/j.jclepro.2011.06.010

LIN, J. W.; HWANG, M. I.; BECKER, J. D. (2003): “A fuzzy neural network for assessing the risk of fraudulent financial reporting", Managerial Auditing Journal, vol. 18, n. 8: 657-665. https://doi.org/10.1108/02686900310495151

LIOU, J. J. H.; CHUANG, Y.; TZENG, G. (2014): “A fuzzy integral-based model for supplier evaluation and improvement", Information Sciences, 266: 199-217. http://dx. doi.org/10.1016/j.ins.2013.09.025.

LOW, K. Y. (2004): "The effects of industry specialization on audit risk assessments and audit-planning decisions", The accounting review, vol. 79, n. 1: 201-219.

MCCRAY, J. H. (1984): “A Quasi-Bayesian Audit Risk Model for Dollar Unit Sampling: A Reply", The Accounting Review, vol. 59, n. 3: 526.

MESSIER JR, W. F.; AUSTEN, L. A. (2000): "Inherent risk and control risk assessments: Evidence on the effect of pervasive and specific risk factors", Auditing: A Journal of Practice \& Theory, vol. 19, n. 2: 119-131. https://doi.org/10.2308/aud.2000.19.2.119

MENTES, A.; AKYILDIZ, H.; YETKIN, M.; TURKOGLU, N. (2015): “A FSA based fuzzy DEMATEL approach for risk assessment of cargo ships at coasts and open seas of Turkey", Safety science, vol. 79: 1-10. https://doi.org/10.1016/ j.ssci.2015.05.004

MOCK, T. J.; WRIGHT, A.; SRIVASTAVA, R. P. (1998): “Audit program planning using a belief function framework", In Proceedings of the 1998 Deloitte $\&$ Touche University of Kansas Symposium on Auditing Problems.

MONROE, G. S.; NG, J. K.; WOODLIFF, D. R. (1993): “The Importance of Inherent Risk Factors: Auditors 'Perceptions", Australian Accounting Review, vol. 3, n. 6:.34-46. https://doi.org/10.1111/j.1835-2561.1993.tb00370.x 
MORTON, J. E.; FELIX JR, W. L. (1991): “A critique of statement on auditing standard No. 55", Accounting Horizons, vol. 5, n.1: 1-10.

NILASHI, M.; ZAKARIA, R.; IBRAHIM, O.; MAJID, M. Z. A.; ZIN, R. M.; FARAHMAND, M. (2015): "MCPCM: a DEMATEL-ANP-based multi-criteria decision-making approach to evaluate the critical success factors in construction projects", Arabian Journal for Science and Engineering, vol. 40, n. 2: 343-361. https://doi.org/10.1007/s13369-014-1529-1

NEHMER, R. A.; SRIVASTAVA, R. P. (2016): "Using Belief Functions in Software Agents to Test the Strength of Application Controls: A Conceptual Framework", International Journal of Intelligent Information Technologies (IJIIT), vol. 12, n. 3: 1-19. https://doi.org/10.4018/ijiit.2016070101

OPPENHEIM, A. N. (2000): Questionnaire design, interviewing and attitude measurement, Bloomsbury Publishing. https://doi.org/10.1016/0149-7189(94)900 21-3

ORTÍZ, M. A.; FELIZZOLA, H. A.; NIETO ISAZA, S. (2015): “A contrast between DEMATEL-ANP and ANP methods for six sigma project selection", BMC Medical Informatics and Decision Making, Vol. 15, n. 3. https://doi.org/10.1186/1472-6947-15-s3-s3

POURJAVAD, E.; SHIROUYEHZAD, H. (2014): "Evaluating manufacturing systems by fuzzy ANP: a case study", International Journal of Applied Management Science, vol. 6, n. 1: 65-83. https://doi.org/10.1504/ijams.2014. 059294

PUBLIC COMPANY ACCOUNTING OVERSIGHT BOARD (2105): PCAOB Inspection Observations Related to PCAOB "Risk Assessment" Auditing Standards (No. 8 through No.15). Washington, D.C: PCAOB.

RITCHIE, B.; KHORWATT, E. (2007): "The attitude of Libyan auditors to inherent control risk assessment", The British Accounting Review, vol. 39, n. 1: 39-59. https://doi.org/10.1016/j.bar.2006.11.001

ROZARIO, A. M.; VASARHELYI, M. A. (2018): “Auditing with smart contracts", The International Journal of Digital Accounting Research, Vol. 18: 127. https://doi.org/10.4192/1577-8517-v18_1 
SAATY, T.L. (1977): “A scaling method for priorities in hierarchical structures", Journal of Mathematical Psychology, vol. 15, n. 3: 234-281. https://doi.org/10.1016/0022-2496(77)90033-5

SAATY, T.L. (1980): The Analytic Hierarchy Process. New York: McGraw-Hill.

SATTY, T. L. (1996): Decision making with dependence and feedback: The analytic network process, RWS Publication.

SAATY, T.L. (2004): "Fundamentals of the analytic network process-multiple networks with benefits, costs, opportunities and risks", Journal of Systems Science and Systems Engineering, vol. 13, n. 3: 348-379. https://doi.org/10.1007/s11518-006-0171-1

SANGAIAH, A. K.; GAO, X. Z.; ABRAHAM, A. (2016): "Handbook of Research on Fuzzy and Rough Set Theory in Organizational Decision Making", IGI Global. https://doi.org/10.4018/978-1-5225-1008-6.

SEVKLI, M.; KOH, S. L.; ZAIM, S.; DEMIRBAG, M.; TATOGLU, E. (2008): "Hybrid analytical hierarchy process model for supplier selection", Industrial Management \& Data Systems, vol. 108, n. 1: 122-142. https://doi.org/ $10.1108 / 02635570810844124$

SPECTOR, S. (2007): GAAP and GAAS 2007/2008 highlights: an update on assurance standards-the audit risk model and related sections, CGA Canada.

SHAFER, G.; SRIVASTAVA, R. (1990): "The Bayesian and belief-function formalisms: A general perspective for auditing", Auditing: A Journal of practice and Theory, vol. 9: 110-148.

SHAFIEE SARDASHT, M.; MORADI, M.; RAHMANI, H. (2014): "An empirical study of factors affecting investors' decisions in the Iranian stock market: a combined Dematel-ANP approach", AESTIMATIO, the ieb international journal of finance, vol. 9: 112-149. https://doi.org/10.5605/ieb.9.6

SHERER, M.; TURLEY, S. (Eds.). (1997): Current Issues in Auditing, SAGE Publications. https://doi.org/10.4135/9781446219133

SHEN, K. Y.; HU, S. K.; TZENG, G. H. (2017): "Financial modeling and improvement planning for the life insurance industry by using a rough knowledge 
based hybrid MCDM model", Information Sciences, 375: 296-313. https://doi.org/10.1016/j.ins.2016.09.055

SIPAHI, S.; TIMOR, M. (2010): “The analytic hierarchy process and analytic network process: an overview of applications", Management Decision, vol. 48, n. 5: 775-808.https://doi.org/10.1108/02517471080000700

SRIVASTAVA, R. P. (2005): "Why we should consider belief functions in auditing research and practice", Auditor's Report, vol. 28, n.2: 58-65.

SRIVASTAVA, R. P. (2011): "An introduction to evidential reasoning for decision making under uncertainty: Bayesian and belief function perspectives", International Journal of Accounting Information Systems, vol. 12, n. 2: 126-135. https://doi.org/10.1016/j.accinf.2010.12.003

SRIVASTAVA, R. P.; DATTA, D. K. (2002): "Evaluating mergers and acquisitions: A belief function approach", In Belief Functions in Business Decisions. Physica-Verlag HD. https://doi.org/10.1007/978-3-7908-1798-0_8

SRIVASTAVA, R. P.; MOCK, T. J. (2002): "Introduction to belief functions, In Belief Functions in Business Decisions . Physica-Verlag HD. https://doi.org/ 10.1007/978-3-7908-1798-0_1

SRIVASTAVA, R. P.; MOCK, T. J.; GAO, L. (2011): “The Dempster-Shafer Theory: An Introduction and Fraud Risk Assessment Illustration", Australian Accounting Review, vol. 21, n.3: 282-291. https://doi.org/10.1111/j.18352561.2011.00135.x

SRIVASTAVA, R. P.; SHAFER, G. R. (2008): Belief-function formulas for audit risk, In Classic Works of the Dempster-Shafer Theory of Belief Functions. Springer Berlin Heidelberg. https://doi.org/10.1007/978-3-540-44792-4_23

SRIVASTAVA, R. P.; SHAFER, G. R. (1992): "Belief-function formulas for audit risk", Accounting Review, vol. 67. n. 2: 249-283. https://doi.org/ 10.1007/978-3-540-44792-4_23

SUN, L.; SRIVASTAVA, R. P.; MOCK, T. J. (2006): “An information systems security risk assessment model under the Dempster-Shafer theory of belief functions", Journal of Management Information Systems, vol. 22, n. 4: 109-142. https://doi.org/10.2753/mis0742-1222220405 
TSAI, S. B.; CHIEN, M. F.; XUE, Y.; LI, L.; JIANG, X.; CHEN, Q.; WANG, L. (2015): "Using the fuzzy DEMATEL to determine environmental performance: a case of printed circuit board industry in Taiwan", PloS one, vol. 10, n. 6. https://doi.org/10.1371/journal.pone.0129153

TSAI, W.H.; CHOU, W.C. (2009): "Selecting management systems for sustainable development in SMEs: A novel hybrid model based on DEMATEL, ANP, and ZOGP", Expert Systems with Applications, vol. 36, n. 2: 1444-1458. https://doi.org/10.1016/j.eswa.2007.11.058

TSENG, M. L. (2009): “Application of ANP and DEMATEL to evaluate the decision-making of municipal solid waste management in Metro Manila", Environmental monitoring and assessment, vol. 156, n. 1-4: 181-197. https://doi.org/10.1007/s10661-008-0477-1

TSENG, M. L. (2011): "Using a hybrid MCDM model to evaluate firm environmental knowledge management in uncertainty", Applied Soft Computing, vol. 11, n. 1: 1340-1352. https://doi.org/10.1016/j.asoc.2010.04.006

TURNER, J. L.; MOCK, T. J.; SRIVASTAVA, R. P. (2002): “A conceptual framework and case studies on audit planning and evaluation given the potential for fraud", Business papers, 58.

TZENG, G. H.; HUANG, J. J. (2011): Multiple attribute decision making: methods and applications, CRC press.

VINODH, S.; BALAGI, T. S.; PATIL, A. (2016): “A hybrid MCDM approach for agile concept selection using fuzzy DEMATEL, fuzzy ANP and fuzzy TOPSIS", The International Journal of Advanced Manufacturing Technology, vol. 83, n. 9-12:1979-1987. https://doi.org/10.1007/s00170-015-7718-6

VINODH, S.; SWARNAKAR, V. (2016): "Deploying Lean Six Sigma framework in an automotive component manufacturing organization", International Journal of Lean Six Sigma, Vol. 7, n. 3: 267293. https://doi.org/10.1108/IJLSS-06-2015-0023

WALLER, W. S. (1994): "Discussion of Motivating Truthful Subordinate Reporting: An Experimental Investigation in a Two-Subordinate Context", Contemporary Accounting Research, vol. 10, n. 2: 721734.https://doi.org/10.1111/j.1911-3846.1994.tb00412.x 
WANG, M. J. J.; CHANG, T. C. (1995): “Tool steel materials selection under fuzzy environment", Fuzzy Sets and Systems, 72, n. 3: 263-270. https://doi.org/ 10.1016/0165-0114(94)00289-j

WANG, R.; LIN, Y. H.; TSENG, M. L. (2011): "Evaluation of customer perceptions on airline service quality in uncertainty", Procedia-Social and Behavioral Sciences, vol. 25: 419-437. https://doi.org/10.1016/j.sbspro.2012. 02.054

WU, W.W. (2008): "Choosing knowledge management strategies by using a combined ANP and DEMATEL approach", Expert Systems with Applications, vol. 35, n. 3: 828-835. https://doi.org/10.1016/j.eswa.2007.07.025

WU, W. W.; LEE, Y. T. (2007): "Selecting knowledge management strategies by using the analytic network process", Expert systems with Applications, vol. 32, n. 3: 841-847. https://doi.org/10.1016/j.eswa.2006.01.029

YAGER, R. R. (1993): Fuzzy screening systems, In Fuzzy Logic. Springer Netherlands. https://doi.org/10.1007/978-94-011-2014-2_24

YEH, T. M.; HUANG, Y. L. (2014): "Factors in determining wind farm location: Integrating GQM, fuzzy DEMATEL, and ANP", Renewable Energy, vol. 66: 159-169. https://doi.org/10.1016/j.renene.2013.12.003

ZESHUI, X.; CUIPING, W. (1999): “A consistency improving method in the analytic hierarchy process", European Journal of Operational Research, vol. 116, n.2: 443-449.https://doi.org/10.1016/s0377-2217(98)00109-x 